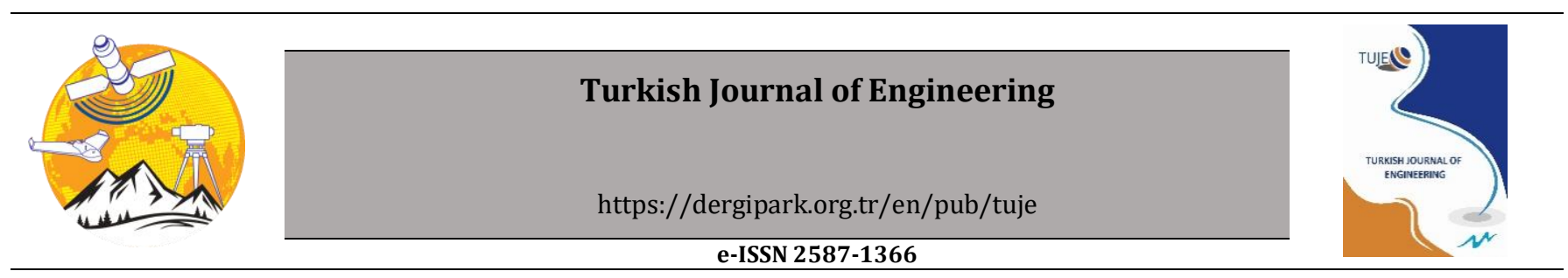

\title{
Mature petroleum hydrocarbons contamination in surface and subsurface waters of Kizilırmak Graben (Central Anatolia, Turkey): Geochemical evidence for a working petroleum system associated with a possible salt diapir
}

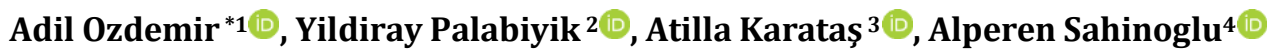 \\ ${ }^{1}$ Adil Ozdemir Engineering \& Consulting, Ankara, Turkey \\ ${ }^{2}$ Istanbul Technical University, Department of Petroleum and Natural Gas Engineering, Istanbul, Turkey \\ 3Marmara University, Faculty of Science and Literature, Geography Department, Istanbul, Turkey \\ ${ }^{4}$ Istanbul Esenyurt University, Institute of Science and Technology, Istanbul, Turkey
}

\author{
Keywords \\ Kizılırmak Graben \\ Reservoir-targeted \\ petroleum exploration \\ TPH in water analysis \\ Hydrocarbon-rich water \\ Salt dome
}

\begin{abstract}
Salt formations exist in Kizılırmak Graben (Central Anatolia, Turkey), which consists of volcano-sedimentary units, and it was stated in previous studies that these formations have a diapiric structure. The adjacent basin, Ayhan Basin, contains bituminous shale and operated coal deposits. For this reason, in this study, it is aimed to investigate the oil and gas potential of the Kizılırmak Graben by conducting TPH (Total Petroleum Hydrocarbons) analysis on the samples taken from natural cold-water resources by making use of the thought that hydrocarbon generation may come into existence from those units in the Ayhan basin. As a consequence of the analyses performed, hydrocarbons have been brought into the open in all the water samples. The organic geochemical methods have been used to find out the source of hydrocarbons determined in the water resources. The disclosed n-alkane hydrocarbons are the mature petroleum hydrocarbons derived from peat/coal type organic matter (Type III kerogen, gas-prone). These mature hydrocarbon-rich waters can be regarded as evidence for the availability of a working hydrocarbon system associated with possible salt diapir identified by using gravity and magnetic data obtained from the investigation area.
\end{abstract}

\section{INTRODUCTION}

The study area is geographically within the Central Anatolia and geologically within the Kırşehir Massif. It is located in the west of the Central Anatolia Fault Zone and in the region situated in the east of the Salt Lake Fault Zone. The regions uplifted between the Salanda and Dadağ faults in and around the study area have been named as the Hırkadağ and Ziyarettepe horst while the region in the south of the horst is called Kizllirmak Graben and Kuyulukışla Graben in the northwest of the horst (Fig. 1) (Demircioğlu, 2014). The investigation area was called Salanda Pull-Apart Basin by Koçyiğit and Doğan (2016). Paleozoic-Quaternary units are present in the area. The basement of the sequence contains Paleozoic-Mesozoic metamorphic rocks. Tertiary sedimentary units unconformably cover these units. Marine units are of Late Paleocene-Middle Eocene. Depending on the climatic conditions and tectonism in the region, lacustrine environments developed in
Miocene and then in micro-scaled basins. In the region, the units formed in the stream environment in different ages and lithologies are also observed. Besides, igneous rocks are quite common in the study area and its surroundings. For this reason, the region is also called the Cappadocia Volcanic Province (Demircioğlu, 2014). In the inspected area, the Alpine orogen phases have become effective and faults and folds have developed based on this orogenesis. NW-SE oriented Tuzköy Fault Set, Salanda, Tuzköy, Yüksekli, and Gülșehir faults are also remarkable faults in the area (Fig. 2).

In Turkey, old aged and thick Tertiary natural salt deposits currently exist. The main deposits of these formations are located in Central Anatolia (Çankırı and Nevşehir regions), Eastern Anatolia (Erzurum region), Southeastern Anatolia (Çukurova region), and Tuz Gölü (Salt Lake) region (Fig. 3) (Kayhan, 1976). The Tuzköy salt deposit in the study area (Nevşehir region) is set foot in the depth of $60 \mathrm{~m}$ from the surface and has the thickness of $150 \mathrm{~m}$ (Fig. 2). In the deposit, 75 million tons 
of proved, 96 million tons of probable and 959 million tons of possible $\mathrm{NaCl}$ reserves have been determined. The presence of rock salt deposits in Gülșehir is not only limited to the Tuzköy rock salt deposit but also continue apart from the deposit (Kayakıran, 1979; Ünüçok, 1985). The folded rock salt deposit formation compatible with an NW-SE extended anticline is covered by younger units (Barutoğlu, 1961; Burkay and Önder, 1986). Rock salt formations in the study area are characterized by a diapiric structure (Bilginer, 1982).

There are numerous oil and gas production areas related to salt structures in the world. In those types of structures in Turkey, any economically viable hydrocarbon field has not been discovered so far and so, any significant hydrocarbon potential could not be determined as well. Therefore, in this study, it has been

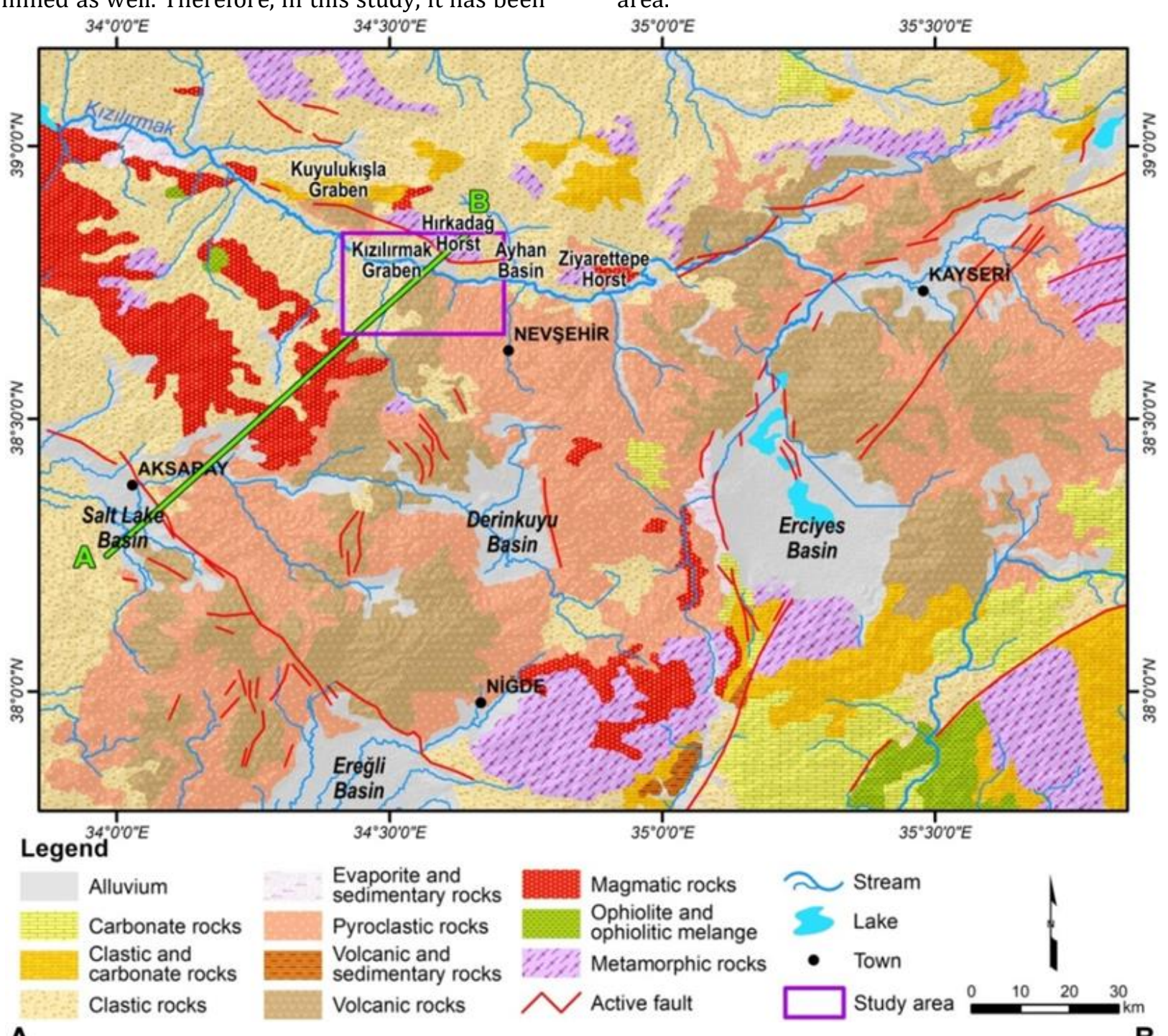

A

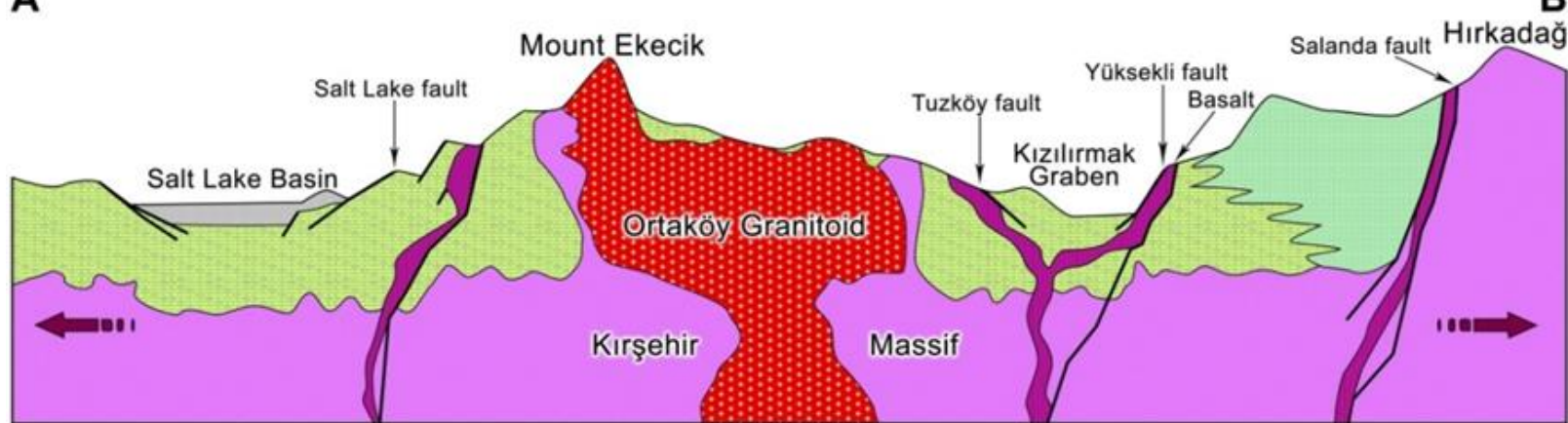

Figure 1. Location map of Kızılırmak Graben (modified from MTA, 2002 and Demircioğlu, 2014)

aimed to identify the salt structure and its hydrocarbon potential based on the findings that it has a diapiric and deep structure which was stated by Bilginer (1982) and that it continues on the outside of the deposit that is the fact that was expressed by Ünüçok (1985). For this purpose, firstly, the possible boundaries of the salt structure are determined by regional gravity and magnetic data. Then, TPH (Total Petroleum Hydrocarbons) analyses are carried out on the samples taken from natural water resources within and around the specified limits. As a result of the analyses, mature petroleum hydrocarbons have been determined in all water samples. The detected mature hydrocarbons can be considered as evidence for a working petroleum system associated with possible salt diapir in the study area.

$\mathbf{B}$ 


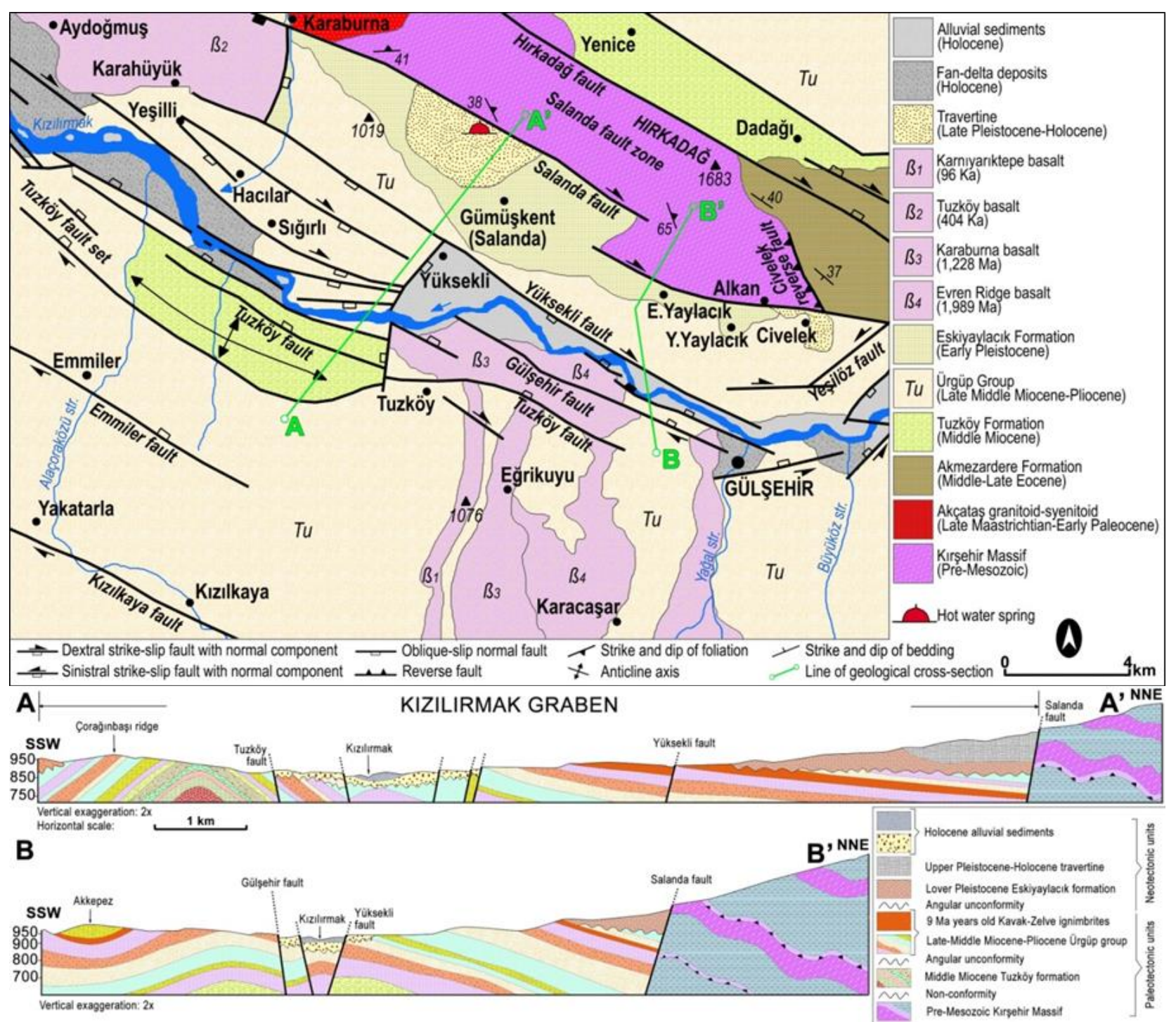

Figure 2. Geology map of the study area (modified from Koçyiğit and Doğan, 2016)

\section{MATERIAL and METHOD}

Eymold et al. (2018) have determined that shallow groundwaters above the basin formations containing shale gas are enriched in hydrocarbons. They have also expressed that the hydrocarbons in these hydrocarbonrich waters migrated from deep source rocks to shallow aquifers. Moreover, Kreuzer et al. (2018) have mentioned that the faults in petroliferous basins make the transportation of hydrocarbon-rich brines to aquifer formations above source rocks easy by influencing the geochemistry of shallow groundwaters and cause a hydrocarbon enrichment in these waters. On the other hand, in recent times, TPH in water analysis has started to be utilized in petroleum exploration, which allows the determination of hydrocarbon-rich waters and organic geochemical properties in basins/regions where source rocks are not exposed at the surface as outcrops (covered basins) or has been exhausted (depleted or spent) (Ozdemir 2019a-c; Karataş et al., 2019; Palabiyik et al., 2019, 2020; Palabiyik and Ozdemir, 2020; Ozdemir et al., 2020). Furthermore, in recent studies, it has been come into existence that all organic geochemical analyses conducted on source rock and gas samples can also be applied to hydrocarbon-rich surface and subsurface waters determined by TPH in water analysis and that the same analysis and interpretation results for the same basins/regions have been reached (Fig. 4) (Ozdemir 2018; Liu et al., 2018). According to these studies, if an oil and/or gas reservoir exists in a region, the surface and subsurface waters in the study area should be rich in mature petroleum hydrocarbons (Fig. 5). Therefore, it can be inferred that the technique of TPH analysis in water will significantly contribute to reservoir-targeted oil and gas exploration activities.

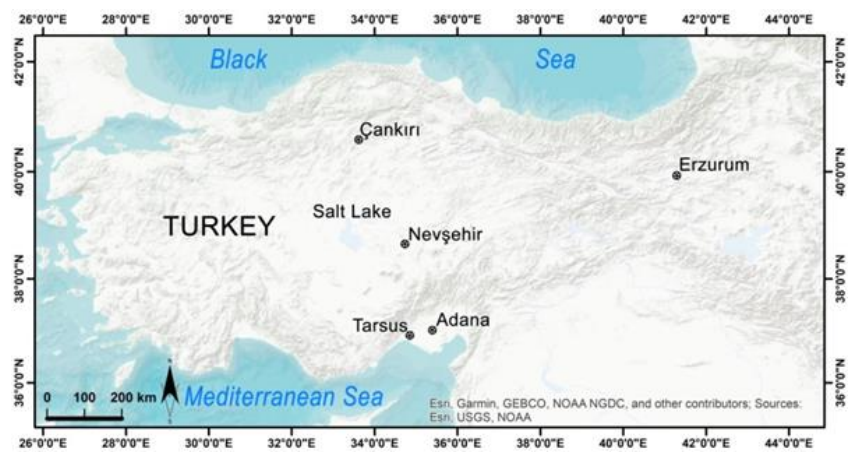

Figure 3. Location map of Tuzköy rock salt mine (Nevşehir) (edited from Kayhan, 1976) 


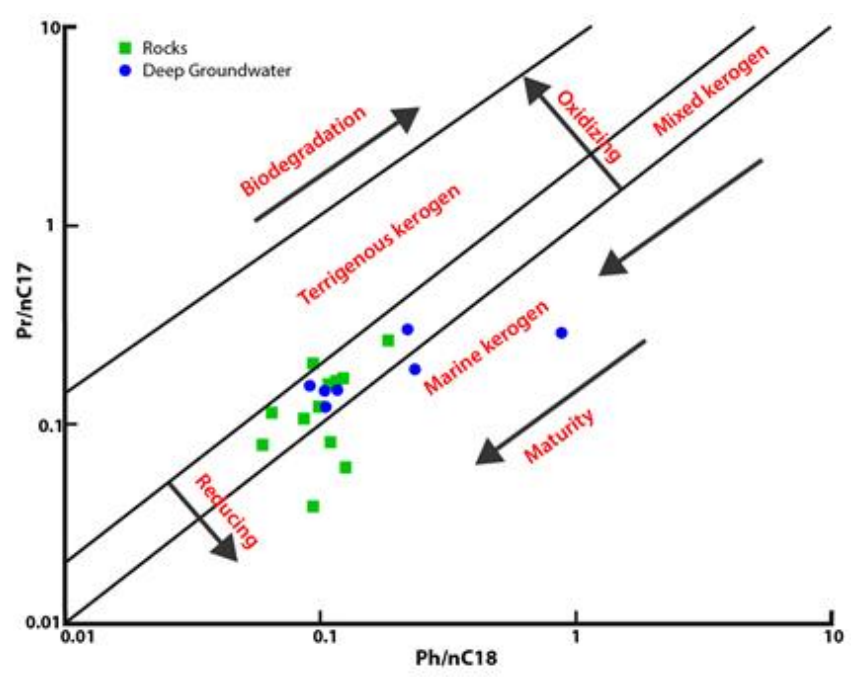

Figure 4. $\mathrm{Ph} / \mathrm{nC} 18$ vs $\mathrm{Pr} / \mathrm{nC} 17$ ratios of deep groundwater and rock samples taken from the same region (Liu et al., 2018) (Pr: Pristane and Ph: Phytane isoprenoid hydrocarbons, $\mathrm{nC} 17$ and nC18: n-alkane hydrocarbons)

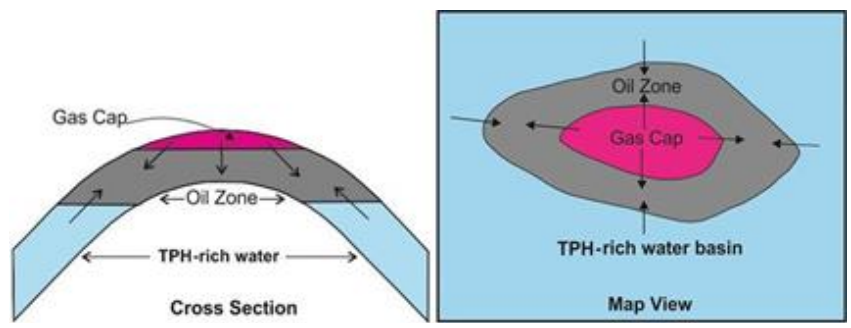

Figure 5. Components of an anticlinal type of petroleum reservoir that can be produced by primary methods (Ozdemir, 2018)

TPH value provides information on hydrocarbon contamination of water resources. Gas chromatography (GC) analyses are performed to detect the TPH concentrations of the water contaminated by hydrocarbons. In the determination of TPH content, the standard test method "the Determination of Hydrocarbons: Solvent extraction and gas chromatography method (ISO 9377-2)" is used (other methods: EPA Method 1664 and ASTM D7678-11). In this technique, aromatic hydrocarbons are separated, and the total amount of petroleum hydrocarbons is determined in the samples taken from the surface, subsurface, and distribution waters. These samples are stored by an acidification process to prevent the issues, which may affect the number of hydrocarbons, such as evaporation or biodegradation in the samples. Samples are analyzed within 14 days if acidified, or they are performed within 7 days if not done, and stored at $5^{\circ} \mathrm{C} \pm 3^{\circ} \mathrm{C}$ before the analysis.

In the comprehension of this research, totally 25 samples have been taken by the scaled polyethylene bottles of 1 liter from the natural flowing waters (cold water fountains) in the region (Figs. 6 and 7). The water samples are taken from the untreated water resources that are not related to tap water (running water). Since the water samples collected from the study area have been analyzed a few days after the sampling, no acidification process has not applied to the samples. They were collected and preserved according to the standard procedures (ISO 5667-3) and analyzed in the laboratory for TPH in water employing the standard methods (ISO 9377-2). In the samples, the TPH analyses have been conducted by a gas chromatography device in the laboratory to generate data for organic geochemical evaluations. Thus, direct TPH concentrations of the water samples (in mg/l) have been determined depending on the analyses and the required geochemical parameters (CPI, NAR, etc.) to be discussed in detail in the next section of the paper have been calculated by making use of gas chromatograms. In the geochemical evaluations, the TPH concentrations and the calculated parameters are utilized.

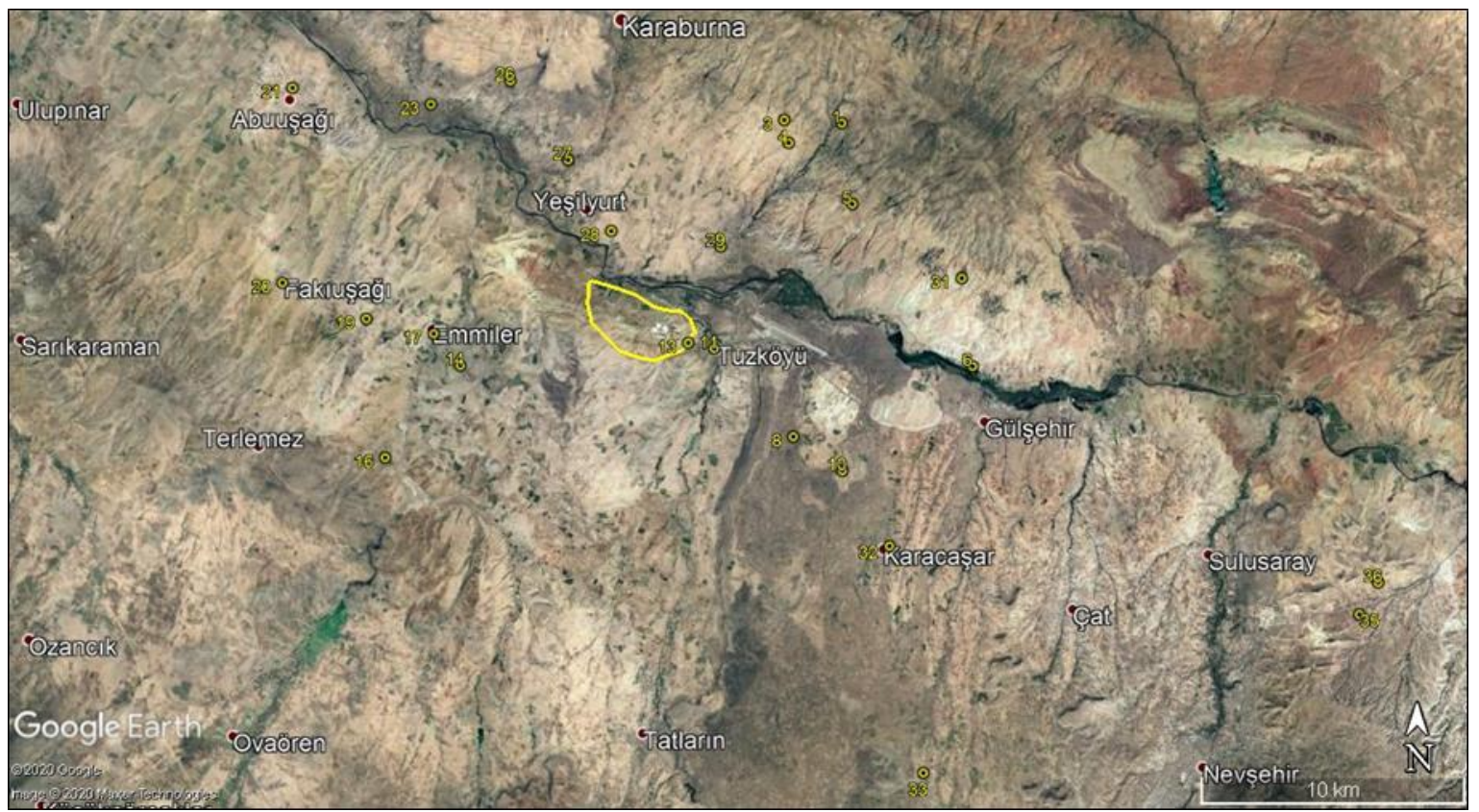

Figure 6. Location map of the taken water samples. Yellow circles: the water samples, yellow polygon: Tuzköy rock salt mine 


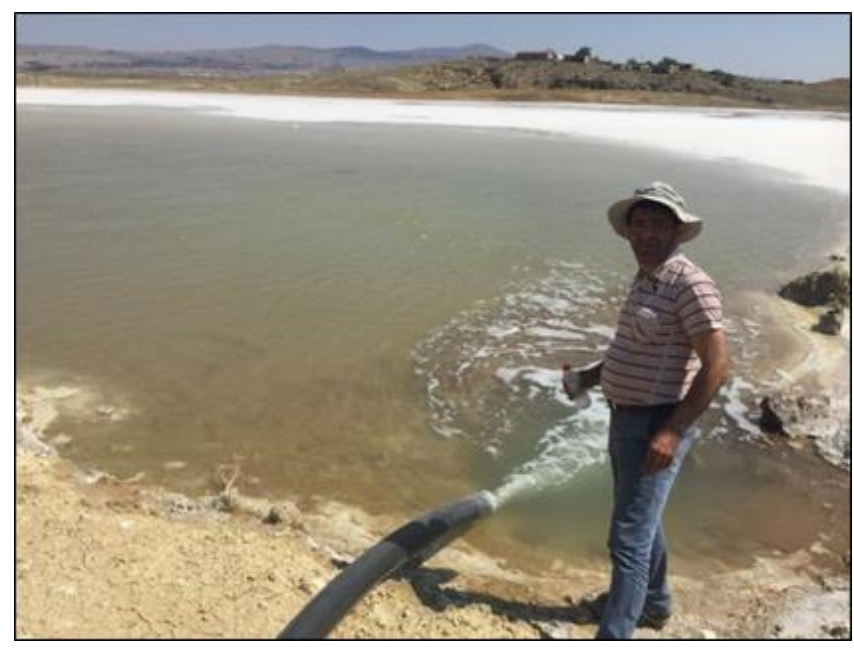

Figure 7. A view of water sampling procedure from cold water fountains (pure and clean natural flowing waters) in the study area by using scaled polyethylene bottles

\section{FINDINGS and DISCUSSION}

Based on the TPH analysis results regarding the water samples taken from the study area, concentrations, biodegradation conditions, source, maturity, and redox conditions of the depositional environment of the hydrocarbons in the waters are investigated in a geochemical point of view. Moreover, the aeromagnetic and gravity maps prepared for the study area are interpreted in terms of geological and tectonic aspects, and the construction of the conceptual occurrence, migration, and accumulation model of the hydrocarbons is targeted.

\subsection{Contents, Source, and Biodegradation of Hydrocarbons in Waters}

Liu et al. (2018) have defined groundwater of which hydrocarbon concentration exceeds $0.05 \mathrm{mg} / \mathrm{l}$ as original hydrocarbon-rich groundwater. The TPH limit values recommended for surface and subsurface waters are given in Table 1. Surface and subsurface waters exceeding the TPH values in Table 1 are defined as hydrocarbon-rich waters. The n-alkane hydrocarbons have been found in all the water samples in the study area. The hydrocarbon content of the water samples is much higher than the limit values suggested for the waters (Tables 1 and 2). Hence, it can be mentioned that water-rock-hydrocarbon interactions have created this hydrocarbon enrichment in waters.

Table 1. The TPH limit values recommended for surface and subsurface waters

\begin{tabular}{ll}
\hline $\begin{array}{l}\text { TPH } \\
(\mathrm{mg} / \mathrm{l})\end{array}$ & Reference \\
\hline$<0.05$ & Liu et al. (2018) \\
$<0.1$ & Zemo and Foote (2003) \\
$<0.5$ & Ozdemir (2018) \\
$<0.2$ & Ministry of Agriculture and Forestry of Turkey \\
& (2004a), Surface Water Quality Regulation of \\
& Turkey (Appendix 5, Table 2: Oil and Grease) \\
$<0.02$ & Ministry of Agriculture and Forestry of Turkey \\
& $\begin{array}{l}\text { (2004b), Water Pollution Control Regulation } \\
\text { of Turkey (Appendices Table 1: Oil and } \\
\end{array}$ \\
& Grease) \\
\hline
\end{tabular}

Table 2. TPH analysis results of the water samples and the calculated parameters

\begin{tabular}{|c|c|c|c|c|c|c|c|c|c|c|c|c|c|c|c|}
\hline \multirow{2}{*}{$\begin{array}{l}\text { Sample } \\
\text { No. }\end{array}$} & \multirow[t]{2}{*}{ Water Resource } & \multicolumn{2}{|c|}{ Coordinates } & \multirow[t]{2}{*}{$\begin{array}{l}\text { TPH } \\
(\mathrm{mg} / \mathrm{l})\end{array}$} & \multirow[t]{2}{*}{ CPI } & \multirow[t]{2}{*}{ TAR } & \multirow[t]{2}{*}{$\mathrm{P}_{\mathrm{aq}}$} & \multirow[t]{2}{*}{$P_{\text {wax }}$} & \multirow[t]{2}{*}{$\begin{array}{l}\text { Waxiness } \\
\text { Index }\end{array}$} & \multirow[t]{2}{*}{ n-C17/n-C31 } & \multirow[t]{2}{*}{ NAR } & \multirow[t]{2}{*}{$\mathrm{Pr} / \mathrm{Ph}$} & \multirow[t]{2}{*}{$\mathrm{Pr} / \mathrm{n}-\mathrm{C} 17$} & \multirow[t]{2}{*}{$\mathrm{Ph} / \mathrm{n}-\mathrm{C} 18$} & \multirow[t]{2}{*}{$\begin{array}{l}\text { n-alkane } \\
\text { maksimum }\end{array}$} \\
\hline & & $\mathrm{x}$ & Y & & & & & & & & & & & & \\
\hline 1 & Natural flowing water & 4300669 & 635154 & 0.52 & 1.24 & - & 0.28 & 0.72 & - & 0.20 & 0.32 & 4.88 & 0.29 & 0.14 & C31 \\
\hline 3 & Mineral water & 4300753 & 632969 & $<0.4$ & 1.34 & - & 0.26 & 0.74 & - & 0.14 & - & 7.67 & 0.39 & 0.13 & C31 \\
\hline 4 & Natural flowing water & 4299892 & 633152 & 0.72 & 1.35 & - & 0.26 & 0.74 & - & 0.15 & 0.25 & 5.84 & 0.26 & 0.10 & C31 \\
\hline 5 & Natural flowing water & 4297621 & 635602 & 0.56 & 1.36 & - & 0.26 & 0.74 & - & 0.19 & 0.23 & 5.95 & 0.29 & 0.09 & C29 \\
\hline 6 & Natural flowing water & 4291566 & 640269 & 0.64 & 1.18 & 5.79 & 0.29 & 0.71 & 4.80 & 0.14 & 0.37 & 10.87 & 0.24 & 0.09 & C31 \\
\hline 8 & Natural flowing water & 4288798 & 633507 & 0.62 & 1.41 & - & 0.23 & 0.77 & - & 0.21 & 0.25 & 5.30 & 0.27 & 0.11 & C31 \\
\hline 10 & Water well & 4287546 & 635389 & 0.63 & 1.27 & 7.91 & 0.22 & 0.78 & - & 0.14 & 0.37 & 5.68 & 0.28 & 0.12 & C31 \\
\hline 11 & Natural flowing water & 4292077 & 630459 & 0.68 & 1.82 & - & 0.10 & 0.90 & 5.58 & 0.10 & 0.27 & 9.28 & 0.25 & 0.08 & C31 \\
\hline 13 & Salt discharge water & 4292277 & 629466 & 0.57 & 1.26 & - & 0.28 & 0.72 & - & 0.15 & 0.29 & 3.63 & 0.21 & 0.13 & C31 \\
\hline 14 & Natural flowing water & 4291278 & 620839 & 0.53 & 1.36 & - & 0.24 & 0.76 & - & 0.15 & 0.25 & 5.45 & 0.30 & 0.10 & C31 \\
\hline 16 & Natural flowing water & 4287752 & 618043 & 0.72 & 1.26 & - & 0.22 & 0.78 & - & 0.13 & 0.37 & 5.61 & 0.23 & 0.10 & C31 \\
\hline 17 & Natural flowing water & 4292465 & 619808 & 0.41 & - & - & - & - & - & 0.11 & - & 8.43 & 0.40 & 0.09 & C31 \\
\hline 19 & Water well & 4292981 & 617241 & 0.52 & 1.55 & - & 0.17 & 0.83 & - & 0.08 & 0.20 & 10.12 & 0.32 & 0.06 & C31 \\
\hline 20 & Natural flowing water & 4294291 & 614037 & 0.43 & 1.60 & 7.70 & 0.18 & 0.82 & 4.27 & 0.12 & 0.10 & 9.95 & 0.30 & 0.08 & C31 \\
\hline 21 & Water well & 4301664 & 614292 & 0.48 & 1.90 & 10.03 & 0.07 & 0.93 & 3.63 & 0.22 & 0.12 & 13.05 & 0.30 & 0.05 & C29 \\
\hline 23 & Natural flowing water & 4301125 & 619556 & 0.53 & 1.71 & 7.91 & 0.12 & 0.88 & 2.95 & 0.11 & 0.08 & 10.00 & 0.24 & 0.06 & C31 \\
\hline 26 & Natural flowing water & 4302065 & 622556 & 0.65 & - & 7.20 & - & - & - & 0.17 & - & 15.95 & 0.25 & 0.04 & C31 \\
\hline 27 & Natural flowing water & 4299109 & 624796 & 0.97 & 1.93 & 7.25 & 0.08 & 0.92 & 3.37 & 0.17 & 0.00 & 4.60 & 0.21 & 0.09 & C31 \\
\hline 28 & Caisson well & 4296453 & 626478 & 0.80 & 1.72 & 7.01 & 0.11 & 0.89 & 1.92 & 0.22 & 0.00 & 5.52 & 0.19 & 0.10 & C29 \\
\hline 29 & Natural flowing water & 4295935 & 630637 & 0.63 & 1.93 & 6.89 & 0.07 & 0.93 & 1.86 & 0.17 & 0.05 & 11.60 & 0.23 & 0.05 & C31 \\
\hline 31 & Natural flowing water & 4294888 & 639800 & 0.60 & 1.75 & - & 0.11 & 0.89 & - & 0.17 & 0.02 & 9.82 & 0.26 & 0.05 & $\mathrm{C} 20$ \\
\hline 32 & Water well & 4284729 & 637224 & 0.54 & 1.85 & - & 0.11 & 0.89 & - & 0.10 & 0.02 & 7.42 & 0.32 & 0.08 & $\mathrm{C} 20$ \\
\hline 33 & Natural flowing water & 4276181 & 638653 & 0.59 & 1.64 & - & 0.17 & 0.83 & - & 0.15 & 0.05 & 18.50 & 0.27 & 0.04 & C29 \\
\hline 35 & Mineral water & 4282436 & 655103 & 0.47 & 1.66 & - & 0.10 & 0.90 & - & 0.32 & 0.12 & 9.43 & 0.24 & 0.07 & $\mathrm{C} 20$ \\
\hline 36 & Mineral water well & 4283652 & 655804 & 0.66 & 1.27 & - & 0.10 & 0.90 & - & 0.10 & - & 7.43 & 0.25 & 0.07 & C31 \\
\hline
\end{tabular}

$\mathrm{CPI}=\{[(\mathrm{C} 23+\mathrm{C} 25+\mathrm{C} 27)+(\mathrm{C} 25+\mathrm{C} 27+\mathrm{C} 29)] /[2 *(\mathrm{C} 24+\mathrm{C} 26+\mathrm{C} 28)]\}$ (Bray and Evans, 1961), TAR = $(\mathrm{C} 27+\mathrm{C} 29+\mathrm{C} 31) /(\mathrm{C} 15+\mathrm{C} 17+\mathrm{C} 19)$ (Bourbonniere and Meyers, 1996$), \mathrm{NAR}=\left[\Sigma \mathrm{n}-\mathrm{alk}\left(\mathrm{C}_{19-32}\right)-2 \Sigma\right.$ even n-alk $\left.\left(\mathrm{C}_{20-32}\right)\right] / \Sigma \mathrm{n}-$ alk ( $\mathrm{C}_{19-32}$ ) (Mille et al., 2007), Waxiness Index: $\sum(\mathrm{n}-\mathrm{C} 21-\mathrm{n}-\mathrm{C} 31) / \sum(\mathrm{n}-\mathrm{C} 15-\mathrm{n}-\mathrm{C} 20)$ (Peters et al., 2005), $\mathrm{P}_{\mathrm{aq}}=$ $(\mathrm{C} 23+\mathrm{C} 25) /(\mathrm{C} 23+\mathrm{C} 25+\mathrm{C} 27+\mathrm{C} 29+\mathrm{C} 31)\left(\right.$ Ficken et al., 2000), $\mathrm{P}_{\mathrm{wax}}=(\mathrm{C} 27+\mathrm{C} 29+\mathrm{C} 31) /(\mathrm{C} 23+\mathrm{C} 25+\mathrm{C} 27+\mathrm{C} 29+\mathrm{C} 31)(\mathrm{Zheng}$ et al., 2007), - : Could not be calculated. 
Source, maturity, migration, and biodegradation are the main elements responsible for the compositional changes in hydrocarbons. $\mathrm{Ph} / \mathrm{n}-\mathrm{C} 18$ value less than 1 indicates non-biodegraded hydrocarbons (Hunt, 1995). $\mathrm{Ph} / \mathrm{n}-\mathrm{C} 18$ values of all the water samples are less than 1 and according to these values, the hydrocarbons in the water samples are in a non-biodegraded character.

By making use of gas chromatography analysis outcomes, the Carbon Preference Index (CPI), Pr/Ph ratio, isoprenoid/n-alkane ratio $(\mathrm{Pr} / \mathrm{nC} 17$ and $\mathrm{Ph} / \mathrm{nC} 18$ ) have been computed, and the n-alkane distributions have been evaluated. In this study, $\mathrm{Pr} / \mathrm{Ph}$ ratio (Didyk et al., 1978; Tissot and Welte, 1984; Banga et al., 2011), Carbon Preference Index (CPI) (Bray and Evans 1961, 1965; Tissot and Welte, 1984), Pr/Ph versus CPI (Onojake et al., 2013; Hakimi et al., 2018), and $\mathrm{Pr} / \mathrm{n}-\mathrm{C} 17$ versus $\mathrm{Pr} / \mathrm{Ph}$ (Syaifudin et al., 2015; Larasati et al., 2016; Devi et al., 2018) plots are utilized to assess the water samples.

CPI is an indicator for the source of n-alkanes. The CPI, a ratio between the amounts of $n$-alkanes with odd and even carbon number, is calculated by measuring the heights of the peaks in gas chromatograms. The dominant peaks in these chromatograms are represented by n-alkanes. In the computation of the CPI, various equations have been proposed by numerous researchers. This index can be applied to any range of the carbon sequence. It is utilized to assess the kind of organic matter, the depositional environment, and thermal maturity. It is remarkably greater than 1 (odd nalkane preferential) or lower than 1 (even n-alkane preferential), indicating thermally immature oil or bitumen samples (Tissot and Welte, 1984; Peters and Moldowan, 1993). A high value of CPI in the immature or low-maturity sample means the input of organic matter derived from higher terrestrial plants (Tran and Philippe, 1993). According to the CPI values (Table 2), the source of n-alkanes in the water samples remarks the petrogenic hydrocarbons and old organic-rich sediments (Table 3).

Table 3. Source of $n$-alkanes in water according to CPI value (Ozdemir, 2018)

\begin{tabular}{|c|c|}
\hline CPI & Source \\
\hline$>2.3$ & $\begin{array}{l}\text { Young terrestrial sediments } \\
\text { (biogenic hydrocarbons) }\end{array}$ \\
\hline $1.2-2.3$ & $\begin{array}{l}\text { Old organic matter-rich sediments (marine } \\
\text { shales, limestones, etc.) }\end{array}$ \\
\hline$\leq 1.2$ & $\begin{array}{l}\text { Petrogenic hydrocarbons } \\
\text { (values }<1 \text { biodegraded oils) }\end{array}$ \\
\hline
\end{tabular}

The term petrogenic sources describe unburned fossil resources like crude oil and coal. These types of sources were formed very slowly at moderate temperatures (between $100^{\circ} \mathrm{C}$ and $300^{\circ} \mathrm{C}$ ) millions of years ago (Beyer et al,. 2010). The parameter NAR (Natural n-alkane Ratio) has been suggested to interpret the source of hydrocarbons in the environment (natural or petroleum n-alkane). This ratio is zero or approximately zero for natural petroleum hydrocarbons and crude oil. In other hydrocarbon sources, those ratios are greater. According to the parameter NAR (Table 2), all the n-alkanes in the water samples indicate natural petroleum (petrogenic) hydrocarbons.
The parameter TAR (Terrestrial/aquatic hydrocarbon ratio) shows the ratio of n-alkanes derived from terrestrial organic matter to n-alkanes derived from aquatic algae (Cranwell et al., 1987; Goossens et al., 1989; Meyers and Ishiwatari, 1993; Bourbonniere and Meyers, 1996). High values of TAR (greater than 1) sign terrestrial plant source and its low values (less than 1) mean marine algae source (Kroon, 2011). The TAR values have been calculated as quite high for the inspected water samples (greater than 1) (Table 2). These values show that the n-alkanes having high carbon numbers indicating terrestrial organic matter are dominant in the water samples in the examined area.

Waxiness index can be utilized to determine the amount of terrestrial organic matter. This index depends on the assumption that regional terrestrial organic matter contributes to extracts with the n-alkane components with high molecular weight (Peters et al., 2005). It is observed that the water samples in the investigation area have high Waxiness values indicating high amounts of biomarkers derived from terrestrial plant (Table 2). This finding is also supported by the fact that the analyzed samples show high TAR values.

The $n-C 17 / n-C 31$ ratio indicates the source of the hydrocarbons derived from the organic matter in the environment. High values (higher than 2) correspond to marine algae while low values (lower than 2) sign land plant sources (Forster et al., 2004). The ratio of n-C17/nC31 of the water samples ranges from 0.08 to 0.32 by indicating the terrestrial organic matter. This consequence is consistent with TAR and Waxiness index values.

By calculating $\mathrm{P}_{\mathrm{aq}}$ and $\mathrm{P}_{\text {wax }}$ parameters, some interpretations can be made about the plant species that make up the organic matter and the paleoclimate conditions of the environment (Zheng et al., 2007). These parameters are used only for coals. If $\mathrm{P}_{\mathrm{aq}}$ value is less than 0.1 , it will mean terrestrial plants; if it is between 0.1 and 0.4 , it will refer to aquatic plants (floated in the swamp environment), and if it is between 0.4 and 1.0 , it will mean that environments exist the presence of plants floated in the water (Ficken et al., 2000). According to $\mathrm{P}_{\mathrm{aq}}$ values (Table 2), the types of plants that constitute the organic matter-deriving hydrocarbons in the water samples are predominantly aquatic plants (floated in the swampy environment). If the $\mathrm{P}_{\text {wax }}$ value is lower than 0.7 , it means dry climate conditions whereas if it is less than 0.7, it will mean the existence of humid climate conditions (Zheng et al., 2007). According to the $\mathrm{P}_{\text {wax }}$ values (Table 2), the organic matter-deriving hydrocarbons in the water samples was formed in dry climate conditions.

\subsection{Maturity of Hydrocarbons in Waters and Redox Conditions of Sedimentation Environment}

CPI value of mature hydrocarbons is equal to 1 or close to 1 (Waples, 1985). The CPI values of oil and bitumen related to very salty carbonate or evaporitic environments are lower than 1 (Tissot and Welte, 1984; Peters and Moldowan, 1993). The maturity level of hydrocarbons is classified based on their CPI values (Table 4) (Onojake et al., 2013), and depending on this 
classification, all the hydrocarbons in the water samples (Table 2) can be classified as mature (more oxidizing) level.

The n-alkanes, which are the closest to isoprenoids in gas chromatograms, are utilized for isoprenoid/nalkane ratios. The $\mathrm{Pr} / \mathrm{Ph}$ ratio is an appropriate correlation parameter. Even though pristane $(\mathrm{Pr})$ and phytane $(\mathrm{Ph})$ define other sources, they are derived from phytyl, which is the side chain of chlorophyll, particularly in phototropic organisms. Under anoxic conditions, the side chain of phytyl breaks down to form the phytol, while phytol is also reduced to pristane under oxic conditions (Peters and Moldowan, 1993). Hence, the $\mathrm{Pr} / \mathrm{Ph}$ ratio shows the redox potential of the depositional environment. $\mathrm{Pr} / \mathrm{Ph}$ values lower than 1 reflect anoxic conditions while the values higher than 1 remark oxic conditions (Didyk et al., 1978; Hunt, 1995). The water samples in the study area exhibit a high $\mathrm{Pr} / \mathrm{Ph}$ ratio varying from 3.63 to 18.50 (Table 2). Therefore, the water samples contain the hydrocarbons derived from sediments deposited in an oxic environment $(\mathrm{Pr} / \mathrm{Ph}>1)$. The $\mathrm{Pr} / \mathrm{Ph}$ ratio also provides information about paleoenvironment and maturity (Volkman and Maxwell, 1986) level. In the $\mathrm{Pr} / \mathrm{Ph}$ versus CPI relationship, it can be observed that the hydrocarbons in the water samples are located in the more oxidizing zone and have similar maturity levels (Fig. 8).

Table 4. The maturity level of hydrocarbons according to CPI value (from Onojake et al., 2013) (see Fig. 8)

\begin{tabular}{ll}
\hline CPI & Maturity \\
\hline$>1$ & Mature (oxidizing-reducing) \\
$0.8-1$ & Mature \\
$<0.8$ & Immature \\
\hline
\end{tabular}

$\mathrm{Pr} / \mathrm{n}-\mathrm{C} 17$ and $\mathrm{Ph} / \mathrm{nC} 18$ ratios are commonly made use of in petroleum correlation studies. Samples containing high Pr reflect an oxidizing source, and high $\mathrm{Ph}$ content indicates a reducing source. Thus, the plot of $\mathrm{Pr} / \mathrm{n}-\mathrm{C} 17$ versus $\mathrm{Ph} / \mathrm{n}-\mathrm{C} 18$ is utilized to distinguish petroleum or bitumen in different groups (Hunt, 1995). Although the $\mathrm{Pr} / \mathrm{Ph}$ ratio above 1.5 shows settling conditions in an oxygenated environment based on a standard geochemical interpretation, it is well-known that it may be lower than 1 for an anoxic depositional environment. Lower values may indicate less suitable oxic conditions than the other parts of the same sequence (Hartkopf-Fröder et al., 2007). The ratio of isoprenoid/nalkane decreases with increasing maturity as more amounts of n-alkanes release from kerogen affected by a breaking down process (Tissot and Welte, 1984; Hunt, 1995) and is used as a degree of maturity for biodegradable oil and bitumen samples. It increases with the biodegradation (Hunt, 1995) and is also affected by organic matter input and secondary phenomena. Depending on their positions in the $\mathrm{Pr} / \mathrm{nC17}$ versus $\mathrm{Ph} / \mathrm{nC} 18$ plot of the water samples, it is observed that the source rocks which generated the hydrocarbons in the water samples are deposited in oxic terrestrial (Type III kerogen, gas-prone) environment and exhibit a high maturity (Figs. 8-12 and Table 5).

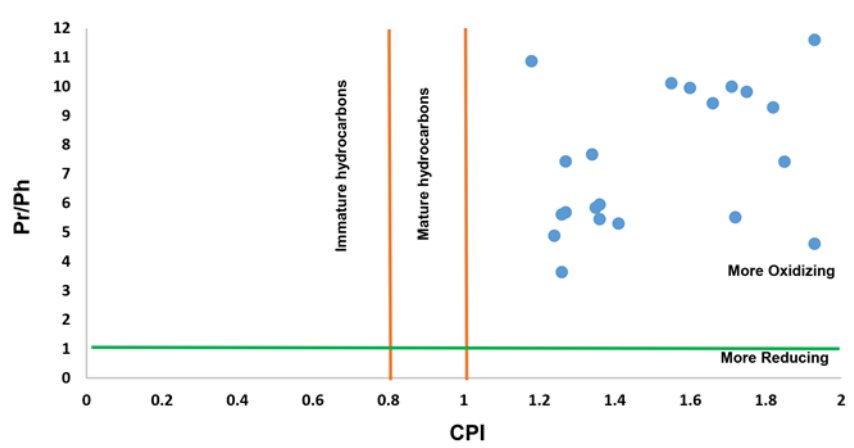

Figure 8. Pr/Ph vs CPI plot of the water samples (the plot: from Onojake et al. 2013)

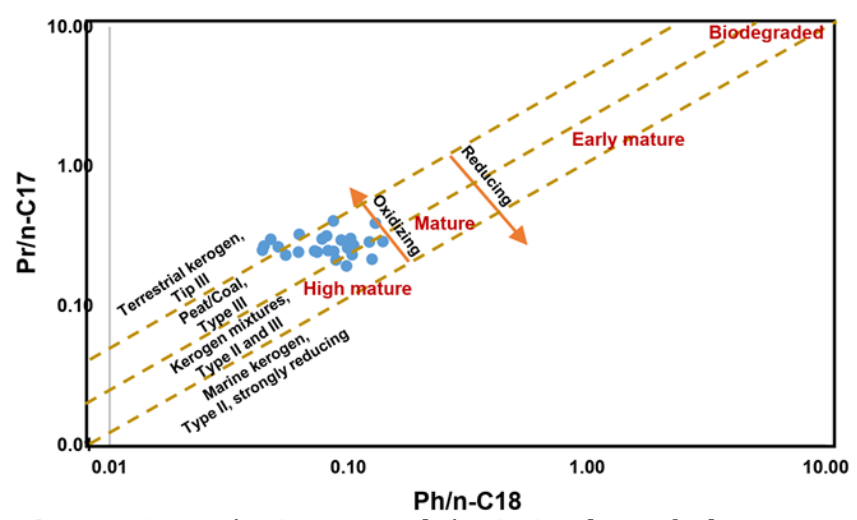

Figure 9. $\mathrm{Pr} / \mathrm{n}-\mathrm{C} 17$ vs $\mathrm{Ph} / \mathrm{n}-\mathrm{C} 18$ plot of the water samples (the plot: from Peters et al. 1999)

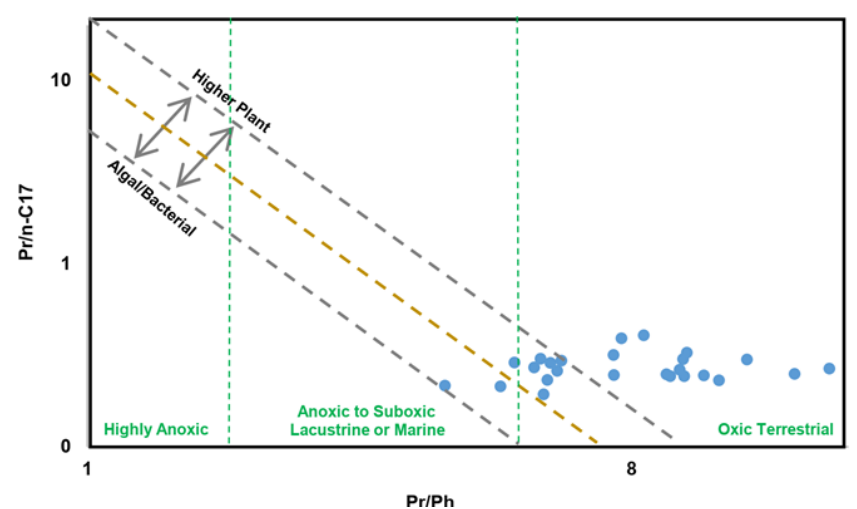

Figure 10. $\mathrm{Pr} / \mathrm{n}-\mathrm{C} 17$ vs $\mathrm{Pr} / \mathrm{Ph}$ plot of the water samples (the plot: Syaifudin et al., 2015; Larasati et al., 2016; Devi et al., 2018)

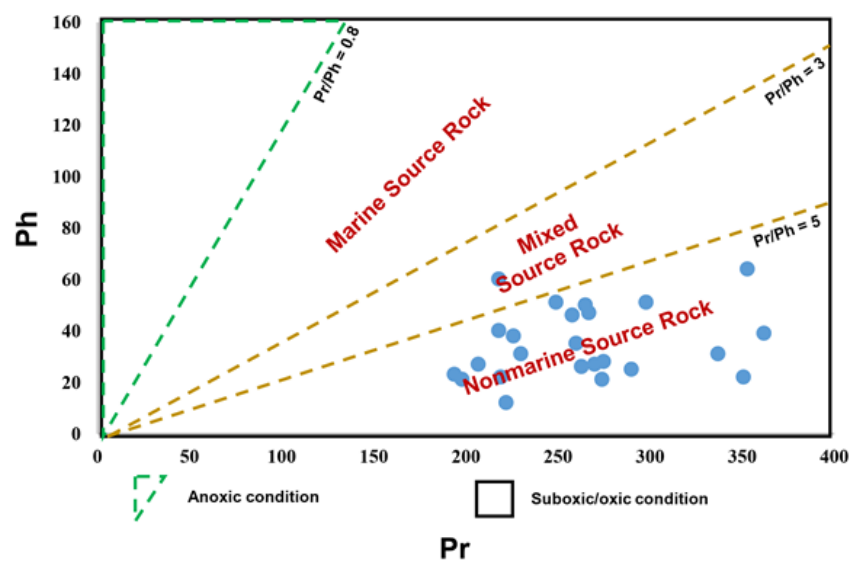

Figure 11. Ph vs Pr plot of the water samples (the plot: from Banga et al., 2011) 


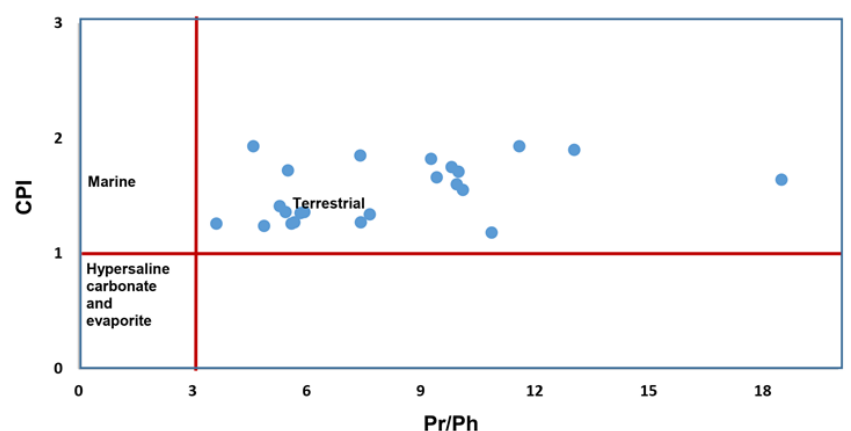

Figure 12. $\mathrm{Pr} / \mathrm{Ph}$ vs $\mathrm{CPI}$ plot of the water samples (the plot: from Hakimi et al., 2018)

Table 5. Source rock and depositional environment of hydrocarbons according to $\mathrm{Pr} / \mathrm{Ph}$ value (from Banga et al. 2011) (see Fig. 11)

\begin{tabular}{llll}
\hline $\mathrm{Pr} / \mathrm{Ph}$ & Source rock & $\mathrm{Pr} / \mathrm{Ph}$ & Environment \\
\hline$<3$ & Marine & $<0.8$ & Anoxic \\
$3-5$ & Marine & $->0.8$ & Suboxic-0xic \\
& Terrestrial & & \\
$>5$ & Terrestrial & & \\
\hline
\end{tabular}

\subsection{Aeromagnetic and Gravity Maps of the Study Area and Geological Interpretations}

There are a lot of studies regarding the methods and field applications of gravity and aeromagnetic data for use in oil and gas exploration (Griffin, 1949; Nettleton, 1976; Geist et al., 1987; Lyatsky et al., 1992; Gadirov, 1994; Piskarev and Tchernyshev, 1997; Pašteka, 2000; Aydın, 1997, 2005; Gadirov and Eppelbaum, 2012; Ivakhnenko et al., 2015; Satyana, 2015; Eke and Okeke, 2016; Stephen and Iduma, 2018; Gadirov et al., 2018; Ozdemir, 2019a-c; Ozdemir et al., 2020). Analysis of gravity and magnetic anomalies has been a permanent component of hydrocarbon exploration and discovery in West Siberia for half a century (Piskarev and Tchernyshev, 1997). In the regions where the existence of mature petroleum hydrocarbons is proved by the determination of hydrocarbon-rich waters in this research, particularly seismic surveys are crucial to determine the locations of oil and gas reservoir(s)/trap(s). Unfortunately, no seismic lines/measurements are available in the investigated area. The contour maps specifically prepared for the study area from regional gravity and aeromagnetic data measured by the General Directorate of Mineral Research and Exploration of Turkey (MTA) have been utilized to evaluate subsurface geology of the area.

Salt diapir-dome structures are characterized by negative gravity anomalies (reverse gravity anomaly) (Nettleton, 1976; Sharma, 1986; Blood, 2001; Jallouli et al., 2005; Pinto et al., 2005; Stadtler et al., 2014; NavaFlores et al., 2016; Constantino et al., 2019; Pourreza and Hajizadeh, 2019). Jallouli et al. (2005) stated that as a result of the misinterpretation of the gravity anomaly observed in salt structures, a positive gravity anomaly of the calculated gravity anomaly can be produced, but the calculated gravity anomaly should produce negative gravity anomaly as compatible with the observed gravity anomaly (Fig. 12). The gravity anomaly of the study area containing Kayatuzu mine is also negative (Fig. 14).

The gravity map prepared for the study area (Fig. 12) contains young sediments composed of lower-density sedimentary origin rocks (siltstone, mudstone, claystone, conglomerate, shale, etc.) and metamorphic (slate, phyllite, etc.) rocks represented by dark blue, light blue, and green colors. In the areas featured by orange, red, and yellow colors, an anomaly is characterized by the rocks having relatively higher densities (crystallized limestone, marble, quartzite, schist, etc.). The study area is limited by strike-slip faults, and the part between the two NW-SE and SE-NW trending main faults has uplifted. This uplifting part was broken with many possible secondary faults.

The prepared aeromagnetic map for the study area (Fig. 12) demonstrates the anomalies that originated from fully non-magnetic sedimentary (sandstone, limestone, siltstone, mudstone, claystone, conglomerate, shale, etc.) and metamorphic (crystallized limestone, marble, quartzite, schist, etc.) rocks represented by blue, green, and light green colors. In the areas represented by yellow, red, and white tones, there are the rocks with magnetic properties (pebbly volcanic sandstones, ophiolites, dikes, etc.). In gravity and magnetic maps prepared for the study area, both the gravity and magnetic anomalies of the possible salt diapir, whose possible limits have been determined, are negative. This result is Koşaroglu et al. (2016) is compatible with the data.

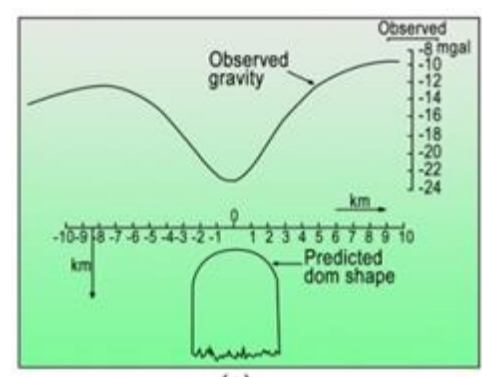

(a)

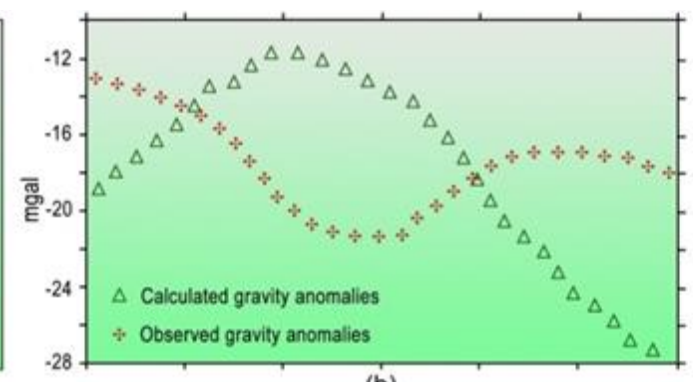

(b)

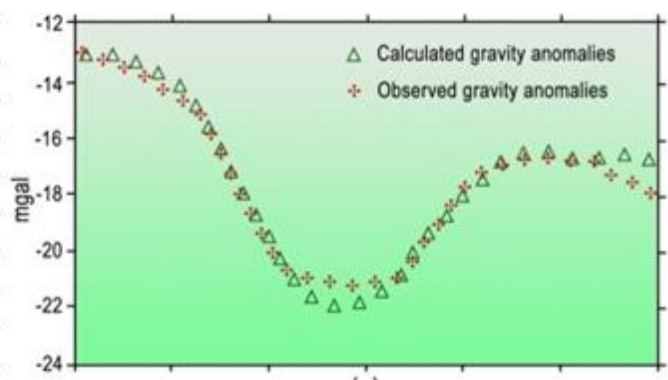

(c)

Figure 13. a. Gravity anomaly of Humble salt dome (Harris Country, Texas, USA) (modified from Nettleton, 1976). b) A mistakenly produced calculated gravity anomaly interpretation for a salt dome, c) a correctly produced calculated gravity anomaly interpretation (modified from Jallouli et al. 2005) 
In the study, the interpretation method proposed by Svancara (1983) and Töpfer (1977) is used to convert the 2D (two-dimensional) residual gravity anomalies into the depth values for the estimation of the basin and structure depths. In this method, if the density contrast is known, the depth of the sedimentary basin or structure can be determined by simple relations established between gravity anomaly and parameters. The first stage of the interpretation gives the characteristic parameters of the anomaly (Figure 13). The relevant equations can be expressed as follows:

$$
A=\frac{g_{m a k}}{W_{a} \sigma}
$$

Where

$g_{\text {mak: }}$ Maximum amplitude of the gravity anomaly,

$W_{a}$ : Distance corresponding to the half amplitude $\left(g_{m a k} / 2\right)$ value of the gravity anomaly,

$\sigma$ : Density contrast.

$$
\begin{gathered}
\frac{W_{b}}{W_{a}}=(-0.056 A)+1.827 \\
D_{o}=23.866 \frac{g_{m a k}}{\sigma}
\end{gathered}
$$

For the condition $0<A<9$ (Töpfer, 1977):

$$
\frac{D}{D_{o}}=0.072 A+1.00
$$

For the condition $9<\mathrm{A}<13$ (Töpfer, 1977):

$$
\frac{D}{D_{o}}=0.12 A+0.57
$$

where

$W_{b}$ : Full width of the gravity anomaly,

$D_{i:}$ : Depth corresponding to the gravity anomaly value,

$D_{o}$ : Depth obtained from the flat-plate formula,

$D$ : Maximum depth.

\subsection{Conceptual Occurrence, Migration, and Trapping Model of Hydrocarbons in the Investigation Area}

Ozdemir (2019a, b), Ozdemir and Palabiyik (2019a, b) and Ozdemir et al. (2020) have mentioned that petroleum source rocks are formed in the mid-ocean ridges and the continental rifts (spreading centers). Hence, Hasandağı, Kızllırmak, and Keçikalesi volcanisms accompanying the extensional regime in the study area, possibly in the Lower (?) - Middle Miocene period, should have caused the formation of the source rocks which generated the hydrocarbons in the water samples (Figs. 1 and 17). Intense volcanic activities (Gürbüz et al. 2019) that have taken place during all Neogene and Quaternary periods are also thought to be effective in maturing of hydrocarbons detected in the water samples.

In the Ayhan basin which is the adjacent basin of the study area, bituminous shale formations and coal deposits characterizing the swampy environment exist in the villages of Avcıköy, Alemli, Dadağı, and Ayhan along with their surroundings (Figs. 1 and 18). In the Ayhan Basin, a partial lacustrine-swampy environment prevailed in the Middle Miocene. Coal units in the basin were deposited in this environment. Lignite veins have the thicknesses ranging from 80 to $100 \mathrm{~cm}$ and their calorific values are quite high (around $5000 \mathrm{kcal}$ ) (Erguvanll, 1954; Reul, 1954; Becker, 1956; Lebküchner, 1957; Wedding, 1967; Inoue, 1967; Akgün et al., 1995; Taka et al. 2004; Demircioğlu, 2014). The n-alkane hydrocarbons determined in the water samples are the mature petroleum hydrocarbons derived from predominantly peat/coal type organic matter (Type-III kerogen, gas-prone) (Fig. 9). Therefore, the hydrocarbons in the water samples may have migrated from the coal beds in the neighboring Ayhan basin and Kuyulukışla graben to the study area. Another possibility is that they may have been derived from the possible coal deposits in the Kizılırmak graben or in the Derinkuyu basin. Gürbüz et al. (2019) have claimed in their paleontological and palynological study that there was a swampy environment in and around the investigation area in the Lower (?) - Middle Miocene and the units of this period contain lignite seams (Fig. 18).

The mature hydrocarbon-rich waters are evidence for a working petroleum system in the study area. The possible gas reservoirs in the study area are the structures around this salt diapir, which is determined by the gravity and magnetic maps (Figs. 16 and 19). The fact that the main structure is located between two strike-slip fault zones empowers the possibility of having accumulated of the hydrocarbons in this structure. The hydrocarbons in the water samples are enriched as a consequence of the water-rock-hydrocarbon interaction with the hydrocarbon-rich geological units in the subsurface and/or mixed with shallow groundwaters migrated from the potential reservoir(s) determined by gravity and magnetic maps.

\section{CONCLUSION}

In this study, which is aimed to investigate the oil and gas potential of Kızılırmak Graben using TPH analysis performed on the samples taken from water resources, the hydrocarbons have been determined in all the water samples. The TPH values are remarkably greater than the hydrocarbon limit values suggested for surface and subsurface waters. The source of the n-alkanes in the water samples are petrogenic hydrocarbons and organicrich sediments. Water-rock-hydrocarbon interactions have caused a hydrocarbon enrichment in the waters in the inspected area, and the hydrocarbons in the water samples are featured by a non-biodegraded character. It is brought out that the source rocks which generated the hydrocarbons in the water samples were deposited in the swamp environment (Type III kerogen, gas-prone) as well as corresponding to the mature-overmature level. The possible gas reservoirs in the study area are the structures around this salt diapir, which is determined by the gravity and magnetic maps. 

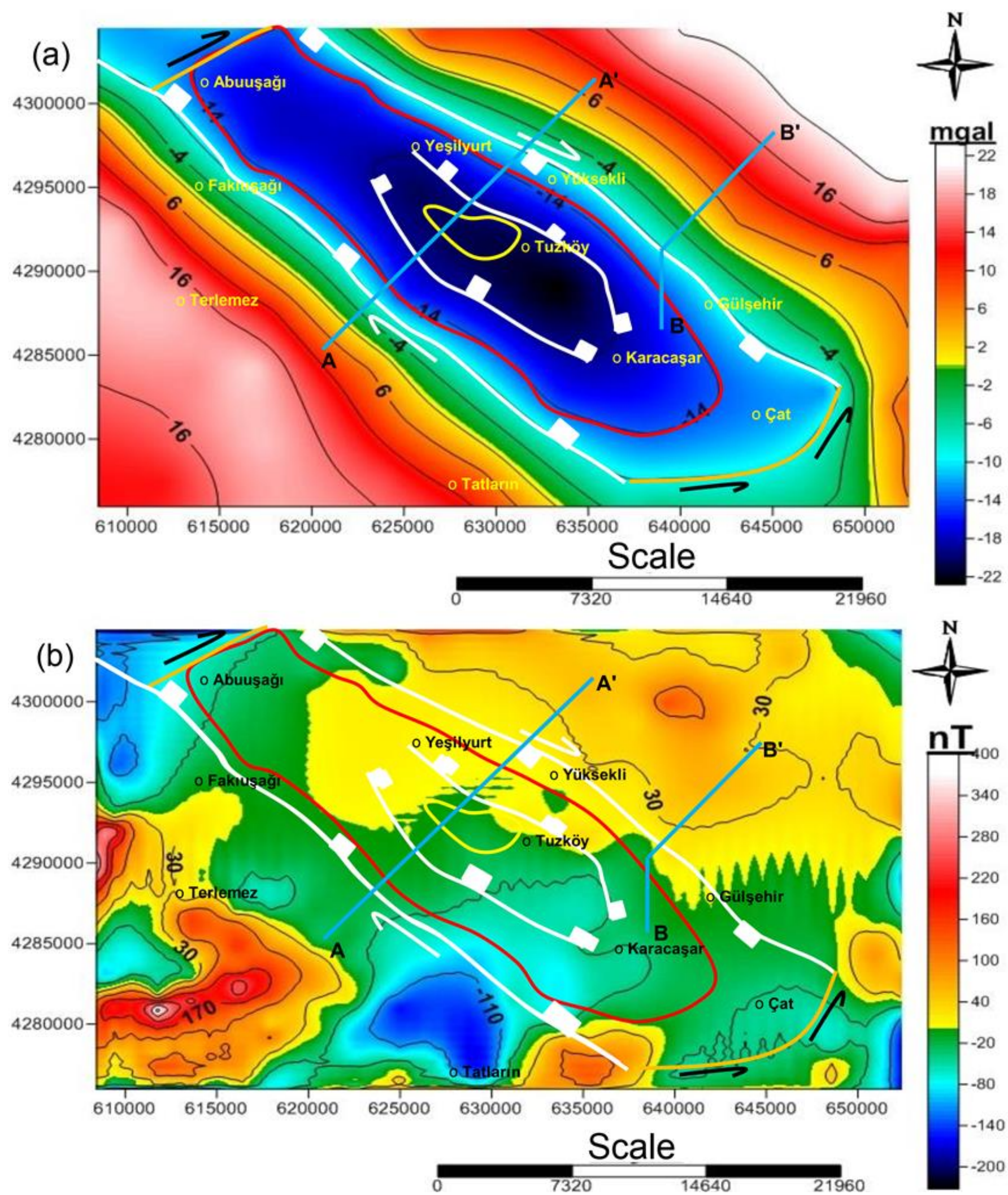

Figure 14. The colored contour maps and geological interpretations of the regional gravity (a) and aeromagnetic (b) anomalies of the study area. Red polygon: possible gas trap in the Kizllırmak Graben, white lines: oblique strike-slip faults (teeth show the hanging wall), A-A 'and B-B': geological cross-section lines (Fig. 3), A-A' line: profile taken to determine the depth of the structure (Fig. 12). 


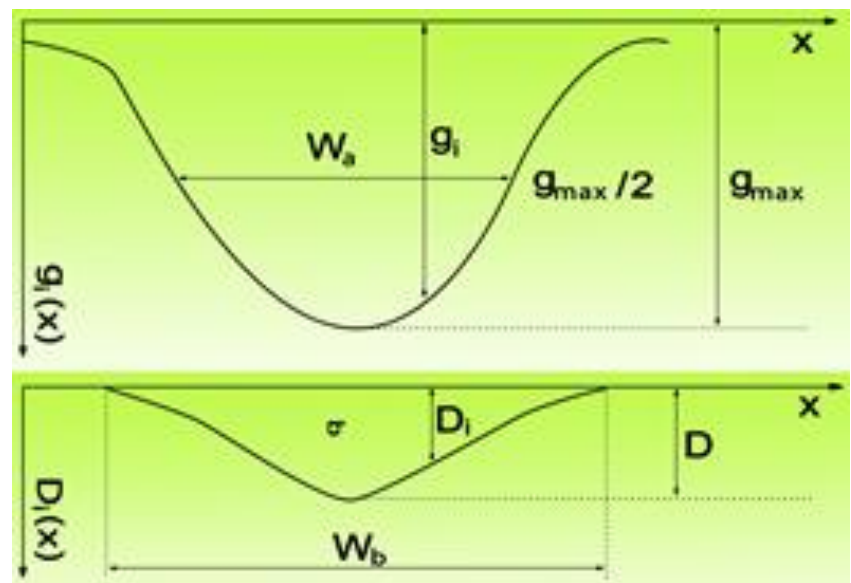

Figure 15. Ideal gravity anomaly of a basin and characteristic parameters (Svancara, 1983)
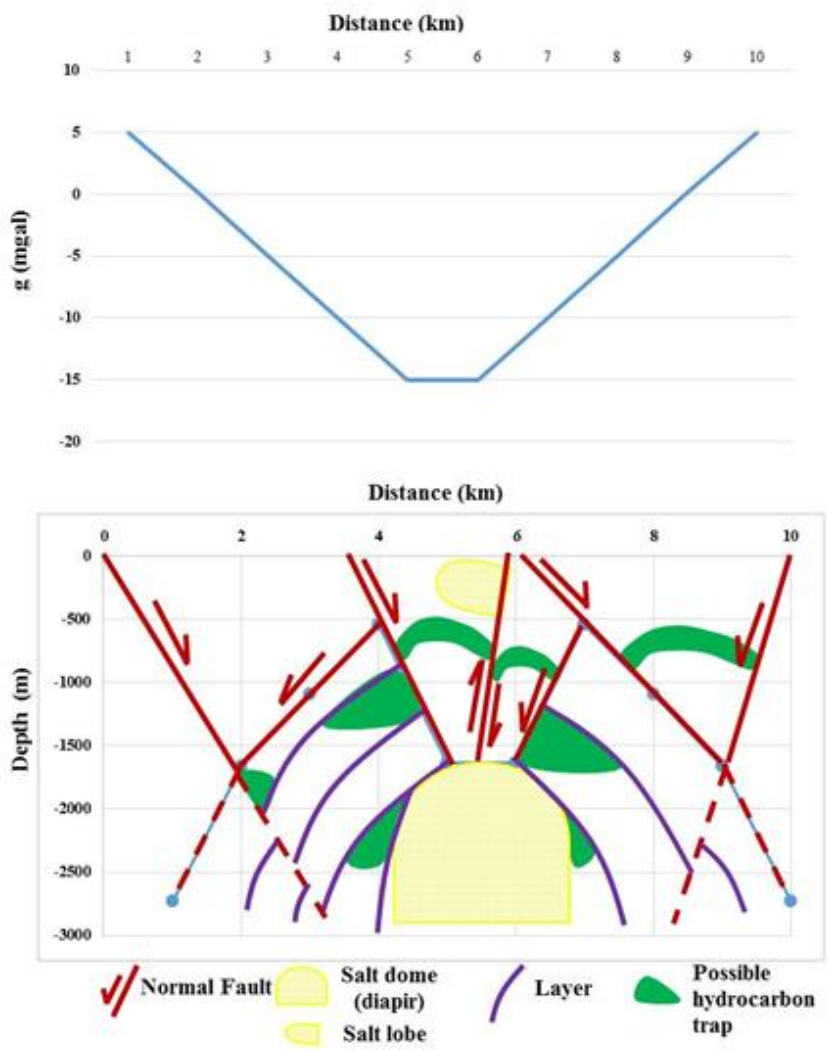

(a) Volcanic basin
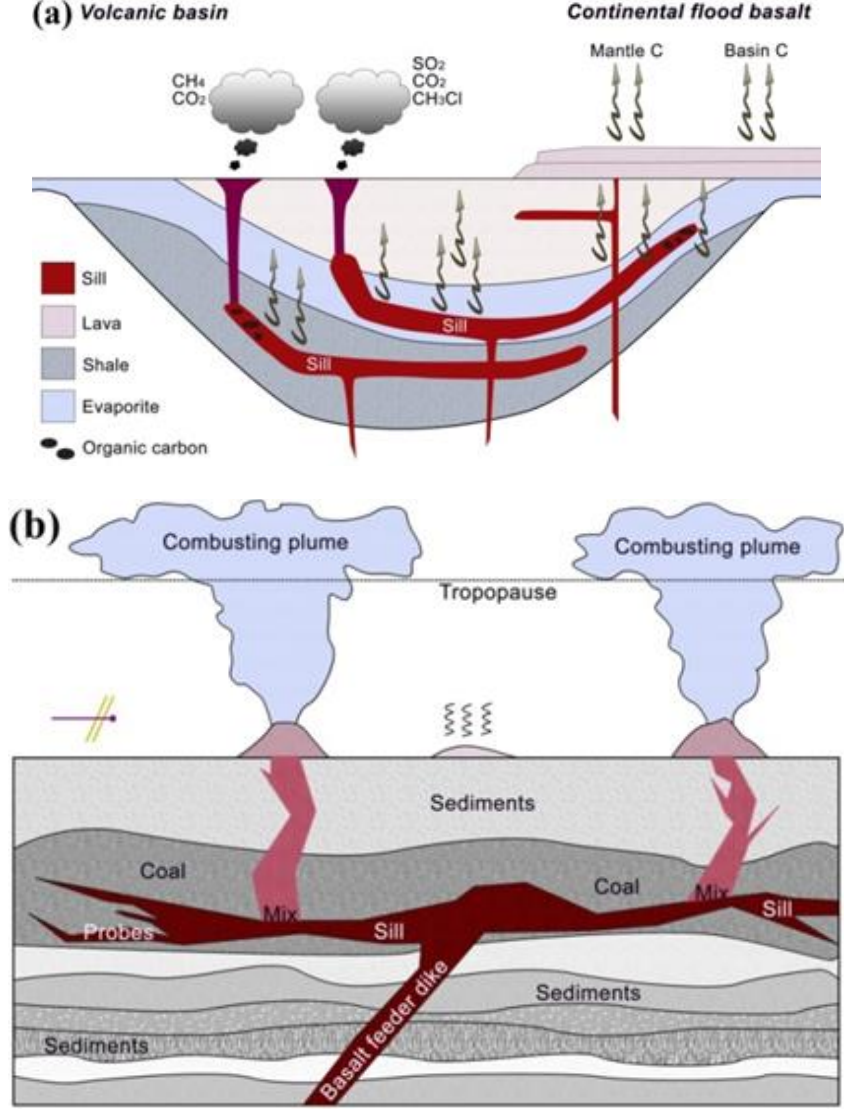

Figure 17. Schematic cross-section showing sil and dykes across a volcanic basin. The chemical composition of sedimentary rocks heated by igneous intrusions has a significant effect on the composition of the metamorphic fluid. For example, organic-rich shale produces $\mathrm{CH}_{4}$ during contact metamorphism, while coal produces $\mathrm{CO}_{2}-$ derived fluids and also water. Many sedimentary basins with sil settlement may contain hydrogen-rich kerogen and oil and gas deposits, and fluids such as methane $\left(\mathrm{CH}_{4}\right)$ and ethane $\left(\mathrm{C}_{2} \mathrm{H}_{6}\right)$ can be enriched in the basin (Svensen et al., 2015). (a: Svensen et al., 2015; b: Ogden and Sleep, 2011)

Figure 16. Geological interpretation of A-A 'profile and depth of the possible salt diapir in the study area (see Fig. 12).
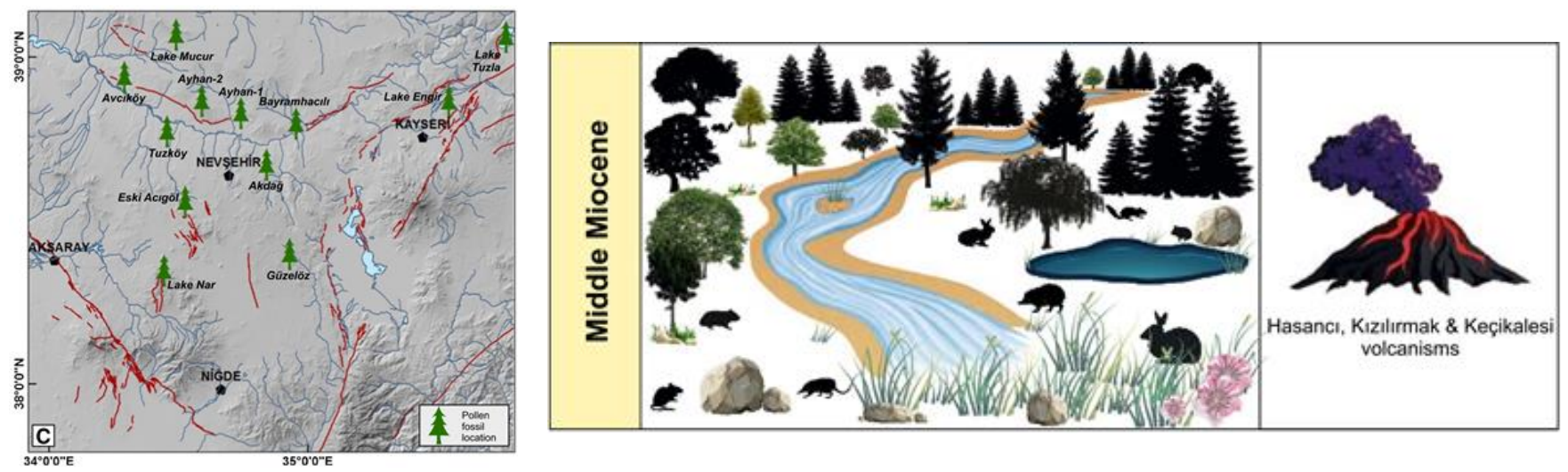

Figure 18. The Miocene paleoenvironment reconstruction based on the geological unit, volcanic age, and palynological data of the study area and its surroundings (Gürbüz et al. 2019) 


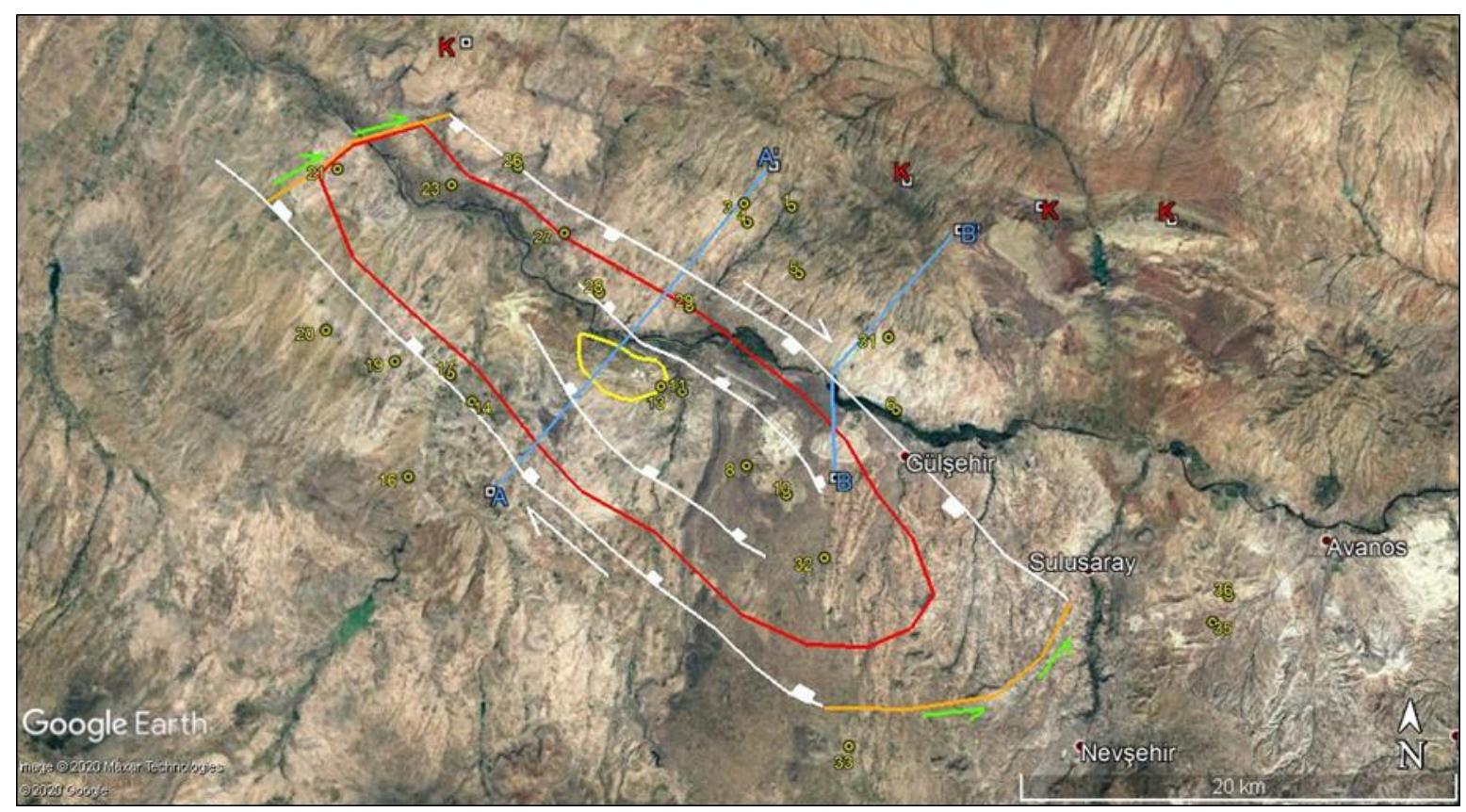

Figure 19. Possible gas trap in the study area (red polygon). White lines: oblique strike-slip faults (teeth show the hanging wall), yellow polygon: Tuzköy rock salt mine, K: coal (lignite) field, A-A' and B-B': geological cross-section lines (Fig. 3), A-A' line: profile taken to estimate the depth of the structure (Fig. 14)

\section{ACKNOWLEDGMENT}

We would like to thank Mr. Serkan Çelebi as well as the experts of SGS Supervise Gözetme Etüd Kontrol Servisleri A.S. for their valuable performances to conduct the required analyses to achieve this research.

\section{Author Contributions}

Adil Ozdemir conceived of the presented idea. He developed the theory and wrote the manuscript. Yildiray Palabiyik verified the analytical methods. He encouraged Adil Ozdemir to investigate [a specific aspect] and supervised the findings of this work. Atilla Karatas carried out the experiments and plotted figures. Alperen Sahinoglu contributed to the design and implementation of the research. All authors discussed the results and contributed to the final manuscript.

\section{Conflicts of interest}

The authors declare no conflicts of interest.

\section{REFERENCES}

ASTM D7678 - 11. Standard Test Method for Total Petroleum Hydrocarbons (TPH) in Water and Wastewater with Solvent Extraction using Mid-IR Laser Spectroscopy

Aydın A (1997). Gravite verilerinin normalize edilmiş tamgradyan, varyasyon ve istatistik yöntemleri ile hidrokarbon açısından değerlendirilmesi, model çalışmalar ve Hasankale-Horasan (Erzurum) Havzasina uygulanması, PhD Thesis, Karadeniz Technical University, Trabzon, Turkey

Aydın A (2005). Gravite anomalilerinın doğrudan yorum yöntemleri ile değerlendirilmesi: Hasankale Horasan bölgesinden bir uygulama. Pamukkale Üniversitesi Mühendislik Bilimleri Dergisi, 11(1), 95102
Akgün F, Olgun E, Kuşçu İ, Toprak V \& Göncüoğlu M C (1995). Orta Anadolu Kristalen Kompleksinin “OligoMiyosen" örtüsünün stratigrafisi, çökelme ortamı ve gerçek yaşına ilişkin yeni bulgular. TPJD bülteni, 6(1), 51-68

Banga T, Capuano R M \& Bissada K K (2011). Petroleum generation in the southeast Texas basin: Implications for hydrocarbon occurrence at the South Liberty salt dome. AAPG Bulletin, 95(7), 1257-1291

Barutoğlu Ö H (1961). Turkey salt deposits. Scientific Mining Journal, 1(2), 68-78

Becker H (1956). Geology and Lignite Deposits of the Region Between Gülşehir and Hacıbektaş (West of Kayseri). Mineral Research and Exploration (MTA), Report No. 2578

Beyer J, Jonsson G, Porte C, Krahn M M \& Ariese F (2010). Analytical methods for determining metabolites of polycyclic aromatic hydrocarbon (PAH) pollutants in fish bile: A review. Environmental Toxicology and Pharmacology, 30(3), 224-244

Bilginer Ö (1982). Geoelectric Survey of Tuzköy Rock Salt Mine (Nevşehir). Mineral Research and Exploration (MTA), Report No. 7270

Blood M F (2001). Exploration for a frontier salt basin in Southwest Oman. The Leading Edge, 20(11), 12521259

Bourbonniere R A \& Meyers P A (1996). Sedimentary geolipid records of historical changes in the watersheds and productivities of lakes Ontario and Erie. Limnology and Oceanography, 41(2), 352-359

Bray E E \& Evans E D (1961). Distribution of n-paraffins as a clue to the recognition of source rocks. Geochimica et Cosmochimica Acta, 22(1), 2-15

Bray E E \& Evans E D (1965). Hydrocarbons in nonreservoir-rock source beds: Part 1. AAPG Bulletin, 49(3), 248-257 
Burkay İ \& Önder İ (1986). Resistivity Survey of Tuzköy Rock Salt Mine (Nevșehir). Mineral Research and Exploration (MTA), Report No. 7875

Constantino R R, Molina E C, de Souza I A \& Vincentelli M G C (2019). Salt structures from inversion of residual gravity anomalies: application in Santos Basin, Brazil. Brazilian Journal of Geology, 49(1), DOI: 10.1590/2317-4889201920180087

Cranwell P A, Eglinton G \& Robinson N (1987). Lipids of aquatic organisms as potential contributors to lacustrine sediments-2. Organic Geochemistry, 11(6), 513-527

Demircioğlu, R. (2014). Gülşehir-Özkonak (Nevşehir) çevresinde Kırşehir masifi ve örtü birimlerinin jeolojisi ve yapısal özellikleri. PhD Thesis, Selçuk University, Konya, Turkey

Devi E A, Rachman F, Satyana A H, Fahrudin \& Setyawan R (2018). Geochemistry of Mudi and Sukowati oils, East Java basin and their correlative source rocks: Biomarkers and isotopic characterisation. Proceedings, Indonesian Petroleum Association, FortySecond Annual Convention \& Exhibition, May 2018

Didyk B M, Simoneit B R T, Brassel S C \& Englington G (1978). Organic geochemical indicators of paleoenvironmental conditions of sedimentation. Nature, 272, 216-222

Eke P O \& Okeke F N (2016). Identification of hydrocarbon regions in Southern Niger Delta Basin of Nigeria from potential field data. International Journal of Scientific and Technology Research, 5(11), 96-99

EPA Method 1664. Revision A: N-Hexane Extractable Material (HEM; Oil and Grease) and Silica Gel Treated N-Hexane Extractable Material (SGTHEM; Non-polar Material) by Extraction and Gravimetry.

Erguvanlı K (1954). Geological Survey of the East of Kırşehir. Mineral Research and Exploration (MTA), Report No. 2373

Eymold W K, Swana K, Moore M T, Whyte C J, Harkness J S, Talma S, Murray R, Moortgat J B, Miller J, Vengosh A \& Darrah T H (2018). Hydrocarbon-rich groundwater above shale-gas formations: A Karoo basin case study. Groundwater, 56(2), 204-224

Forster A, Sturt H \& Meyers P A (2004). Molecular biogeochemistry of Cretaceous black shales from the Demerara Rise: Preliminary shipboard results from sites 1257 and 1258, Leg 207. in Erbacher, J., Mosher, D.C., Malone, M.J., et al., Proceedings of the Ocean Drilling Program, Initial Reports: 207, 1-22.

Gadirov V G, Eppelbaum L V, Kuderavets R S, Menshov 0 I \& Gadirov K V (2018). Indicative features of local magnetic anomalies from hydrocarbon deposits: examples from Azerbaijan and Ukraine. Acta Geophysica, 66(6), 1463-1483. DOI: 10.1007/s11600018-0224-0

Gadirov V G \& Eppelbaum L V (2012). Detailed gravity, magnetics successful in exploring Azerbaijan onshore areas. Oil and Gas Journal, 110(11), 60-73

Gadirov V G (1994). The physical-geological principles of application of gravity and magnetic prospecting in searching oil and gas deposits. Proceed. of 10th Petroleum Congress and Exhibition of Turkey, Ankara, 197-203
Geist E L, Childs J R \& Scholl D W (1987). "Evolution and petroleum geology of Amlia and Amukta intra-arc summit basins, Aleutian Ridge". Marine and Petroleum Geology, 4(4), 334-352

Goossens H, Duren C, De Leeuw J W \& Schenck P A (1989). Lipids and their mode of occurrence in bacteria and sediments-2. Lipids in the sediment of a stratified, freshwater lake. Organic Geochemistry, 14(1), 27-41

Griffin W R (1949). Residual gravity in theory and practice. Geophysics, 14(1), 39-58

Gürbüz A, Saraç G \& Yavuz N (2019). Paleoenvironments of the Cappadocia region during the Neogene and Quaternary, central Turkey. Mediterranean Geoscience Reviews, 1(2), 271-296.

Hakimi M H, Al-Matary A M \& Ahmed A (2018). Bulk geochemical characteristics and carbon isotope composition of oils from the Sayhut sub-basin in the Gulf of Aden with emphasis on organic matter input, age and maturity. Egyptian Journal of Petroleum, 27(3), 361-370

Hartkopf-Fröder C, Kloppisch M, Mann U, NeumannMahlkau P, Schaefer R G \& Wilkes H (2007). The endFrasnian mass extinction in the Eifel Mountains, Germany: new insights from organic matter composition and preservation. Geological Society, London, Special Publications, 278(1), 173-196. DOI: 10.1144/SP278.8

Hunt J M (1995). Petroleum Geochemistry and Geology. W.H. Freeman and Company, New York

Inoue E (1967). Geology and Coal Reserves of Dadağ1Arafa Coal Field. Mineral Research and Exploration (MTA), Report No. 3948

ISO 5667-3. Water Quality - Sampling - Part 3: Preservation and Handling of Water Samples.

ISO 9377-2. Water Quality - Determination of Hydrocarbon Oil Index - Part 2: Method Using Solvent Extraction and Gas Chromatography.

Ivakhnenko O P, Abirov R \& Logvinenko A (2015). New method for characterisation of petroleum reservoir fluid-mineral deposits using magnetic analysis. Energy Procedia, 76, 454-462

Jallouli C, Chikhaoui M, Braham A, Turki M M, Mickus K \& Benassi R (2005). Evidence for Triassic salt domes in the Tunisian Atlas from gravity and geological data. Tectonophysics, 396, 209-225

Karatas A, Ozdemir A \& Sahinoglu A (2019). Investigation of Oil and Gas Potential of Karaburun Peninsula and Seferihisar Uplift (Western Anatolia) by Iodine Hydrogeochemistry and Total Petroleum Hydrocarbon (TPH) in Water Analysis. Marmara University, Project No (9505): SOS-A-100719-0267

Kayakıran S (1979). Research and Exploration of Gülşehir Rock Salt Mine (Studies in 1977 and 1978). Mineral Research and Exploration (MTA), Report No. 6606

Kayhan M (1976). Turkey Salt Inventory. Mineral Research and Exploration (MTA), Publication No: 164, 78

Koçyiğit A \& Doğan U (2016). Strike-slip neotectonic regime and related structures in the Cappadocia region: a case study in the Salanda basin, Central 
Anatolia, Turkey. Turkish Journal of Earth Sciences, 25(5), 393-417

Kosaroglu S, Buyuksarac A \& Aydemir A (2016). Modeling of shallow structures in the Cappadocia region using gravity and aeromagnetic anomalies. Journal of Asian Earth Sciences, 124, 214-226

Kreuzer R L, Darrah T H, Grove B S, Moore M T, Warner N R, Eymold W K \& Poreda R J (2018). Structural and hydrogeological controls on hydrocarbon and brine migration into drinking water aquifers in Southern New York. Groundwater, 56(2), 225-244

Kroon J (2011). Biomarkers in the Lower Huron Shale (Upper Devonian) As Indicators of Organic Matter Source, Depositional Environment, and Thermal Maturity. MSc. Thesis, Clemson University, US.

Larasati D, Suprayogi K \& Akbar A (2016). Crude oil characterization of Tarakan basin: Application of biomarkers. The 9th International Conference on Petroleum Geochemistry in the Africa - Asia Region, Bandung, Indonesia, 15 -17 November 2016

Lebküchner R F (1957). Geology of Kayseri and AvanosÜrgüp-Boğazliyan. Mineral Research and Exploration (MTA), Report No. 2656

Liu S, Qi S, Luo Z, Liu F, Ding Y, Huang H, Chen Z \& Cheng $S$ (2018). The origin of high hydrocarbon groundwater in shallow Triassic aquifer in Northwest Guizhou, China. Environmental Geochemistry and Health, 40(1), 415-433

Lyatsky H V, Thurston J B, Brown R J \& Lyatsky V B (1992). Hydrocarbon exploration applications of potential field horizontal gradient vector maps. Canadian Society of Exploration Geophysicists Recorder, 17(9), 10-15

Meyers P A \& Ishiwatari R (1993). Lacustrine organic geochemistry-an overview of indicators of organic matter sources and diagenesis in lake sediments. Organic Geochemistry, 20(7), 867-900

Mille G, Asia L, Guiliano M, Malleret L \& Doumenq P (2007). Hydrocarbons in coastal sediments from the Mediterranean Sea (Gulf of Fos area, France). Marine Pollution Bulletin, 54(5), 566-575

Ministry of Agriculture and Forestry of Turkey, 2004a. Surface Water Quality Regulation of Turkey, http://www.resmigazete.gov.tr/eskiler/2016/08/2 0160810-9.htm (Accessed 02 June 2020)

Ministry of Agriculture and Forestry of Turkey, 2004b. Water Pollution Control Regulation of Turkey (in Turkish),http://www.mevzuat.gov.tr/Metin.Aspx?M evzuatKod=7.5.7221\&Mevzuatlliski=0\&sourceXmlSe arch= (Accessed 02 June 2020)

MTA (General Directorate of Mineral Research and Exploration) (2002) Geological Map of Turkey: General Directorate of Mineral Research and Exploration Publication, scale 1/500,000, 18 sheets

Nava-Flores M, Ortiz-Aleman C, Orozco-del-Castillo M G Urrutia-Fucugauchi J, Rodriguez-Castellanos A, Couder-Castañeda C \& Trujillo-Alcantara A (2016). 3D gravity modeling of complex salt features in the Southern Gulf of Mexico. International Journal of Geophysics, 1702164, 12

Nettleton L L (1976). Gravity and Magnetics in Oil Prospecting. McGraw-Hill
Ogden DE, Sleep NH, (2011) Explosive eruption of coal and basalt and the end-Permian mass extinction. Earth, Atmospheric, and Planetary Sciences, 109(1): 59-62.

Onojake M C, Osuji L C \& Oforka N C (2013). Preliminary hydrocarbon analysis of crude oils from Umutu/Bomu fields, southwest Niger Delta, Nigeria. Egyptian Journal of Petroleum, 22(2), 217-224

Ozdemir A (2018). Usage of the Total Petroleum Hydrocarbons (TPH) in water analysis for oil and gas exploration: First important results from Turkey. Journal of Engineering Sciences and Design, 6(4), 615636

Ozdemir A (2019a). Organic hydrogeochemical evidence of Hasanoğlan (Ankara) petroleum system. Pamukkale University Journal of Engineering Sciences, 25(6), 748-763

Ozdemir A (2019b). Mature hydrocarbons-rich waters as geochemical evidence of working petroleum system of Mamak (Ankara) and potential trap area in the region. European Journal of Science and Technology, $17,244-260$

Ozdemir A (2019c). Organic hydrogeochemical evidence of pre-Neogene petroleum system of the Buyuk Menderes graben and potential traps (Western Turkey). European Journal of Science and Technology, $16,325-354$

Ozdemir A \& Palabiyik Y (2019a). A review of Paleozoic Miocene petroleum source rocks of Turkey by paleogeographic and paleotectonic data: New interpretations and major outcomes. 7th International Symposium on Academic Studies in Science, Engineering and Architecture Sciences, November 15-17, Ankara, Turkey, 689-725

Ozdemir A \& Palabiyik Y (2019b). A new approach to petroleum source rock occurrence: The relationships between petroleum source rock, ophiolites, mantle plume and mass extinction. IV. International Congress of Scientific and Professional Studies - Engineering (BILMES EN), November 07 - 10, Ankara, Turkey, 2839

Ozdemir A, Karataş A, Palabiyik Y, Yaşar E \& Sahinoglu A (2020). Oil and gas exploration in Seferihisar Uplift (Western Turkey) containing an operable-size gold deposit: Geochemical evidence for the presence of a working petroleum system. Geomechanics and Geophysics for Geo-Energy and Geo-Resources, 6(1), DOI: $10.1007 / s 40948-020-00152-2$

Palabiyik Y, Ozdemir A \& Sahinoglu A (2019). Investigation of Oil and Gas Potential of Uludag Massif (Northwestern Anatolia) by Iodine Hydrogeochemistry and Total Petroleum Hydrocarbon (TPH) in Water Analysis, Istanbul Technical University, Scientific Research Project, Project No: MAB-2019-42217, 76 p.

Palabiyik Y \& Ozdemir A (2020). Use of TPH (Total Petroleum Hydrocarbons) in water analysis for oil and gas exploration in Turkey: The case studies from Western, Northwestern and Central Anatolia regions and major outcomes. Turkey IV. Scientific and Technical Petroleum Congress, October 26-28, Ankara, Turkey (in press) 
Palabiyik Y, Ozdemir A, Karataş A \& Özyağcı M (2020). Identification of Oil and Gas Potential of Kastamonu and Sinop and their Surroundings (Central Pontides) by Using Total Petroleum Hydrocarbons (TPH) in Water Analysis, Istanbul Technical University, Scientific Research Project, Project No: MGA-202042587 (continue)

Pašteka R (2000). 2D semi-automated interpretation methods in gravimetry and magnetometry. Acta Geologica Universitatis Comeniana, 55, 5-50

Peters K E, Walters C C \& Moldowan J M (2005). The Biomarker Guide: Biomarkers and Isotopes in Petroleum Exploration and Earth History, Second Ed, Vol 2. Cambridge University Press

Peters K E, Fraser T H, Amris W, Rustanto B \& Hermanto E (1999). Geochemistry of crude oils from eastern Indonesia. AAPG Bulletin, 83, 1927-1942

Peters K E \& Moldowan J M (1993). The Biomarker Guide, Interpreting Molecular Fossils in Petroleum and Ancient Sediments. Englewood Cliffs, Jersey, Prentice Hall

Pinto V, Casas A, Rivero L \& Torne M (2005). 3D gravity modeling of the Triassic salt diapirs of the Cubeta Alavesa (northern Spain). Tectonophysics, 405, 65-75

Piskarev A L \& Tchernyshev M Y (1997). Magnetic and gravity anomaly patterns related to hydrocarbon fields in northern West Siberia. Geophysics, 62(3), 831-841

Pourreza S \& Hajizadeh F (2019). Simulation of a salt dome using 2D linear and nonlinear inverse modeling of residual gravity field data. Bulletin of the Mineral Research and Exploration, 160, 231-244

Reul K (1954). Lignite occurrences around Kayseri. Mineral Research and Exploration (MTA), Report No. 2240

Satyana A H (2015). Subvolcanic hydrocarbon prospectivity of Java: Opportunities and challenges. Proceedings, Indonesian Petroleum Association. Thirty-Ninth Annual Convention \& Exhibition, May 2015. IPA15-G-105

Sharma P V (1986). Geophysical Methods in Geology (2nd Edition). Elsevier

Stadtler C, Fichler C, Hokstad K, Myrlund E A, Wienecke S \& Fotland B (2014). Improved salt imaging in a basin context by high resolution potential field data: Nordkapp Basin, Barents Sea. Geophysical Prospecting, 2014, 62, 615-630

Stephen O I \& Iduma U (2018). Hydrocarbon potential of Nigeria's Inland Basin: Case study of Afikpo basin. Journal of Applied Geology and Geophysics, 6(4), 1-24

Svancara J (1983). Approximate method for direct interpretation of gravity anomalies caused by surface three-dimensional geologic structures. Geophysics, 48(3), 361-366 https://doi.org/10.1190/1.1441474
Svensen H, Fristad KE, Polozov AG, Planke S. (2015) Volatile generation and release from continental large igneous provinces. In: Schmidt, A., Fristad, K.E., and Elkins-Tanton, L.T., (Eds.), Volcanism and Global Environmental Change, Cambridge University Press, UK, https://doi.org/10.1017/CB09781107415683.015

Syaifudin M, Eddy A, Subroto E A, Noeradi D \& Kesumajana A H P (2015). Characterization and correlation study of source rocks and oils in Kuang area, South Sumatra basin: The potential of Lemat formation as hydrocarbon source rocks. Proceedings of Indonesian Petroleum Association, Thirty-Ninth Annual Convention \& Exhibition, May 2015, IPA15-G034

Taka M, Dümenci S, Kalkan İ \& Şener M (2004). Sedimentology and Coal Potential of Tertiary Cover of the Central Anatolian Crystalline Complex. Mineral Research and Exploration (MTA), Report No. 10722

Tissot B P \& Welte D H (1984). Petroleum Formation and Occurrence. Springer-Verlag

Töpfer K D (1977). Improved technique for rapid interpretation of gravity anomalies caused by twodimensional sedimentary basins. Journal of Geophysics, 43, 645-654

Tran K L \& Philippe B (1993). Oil and rock extract analysis. Applied Petroleum Geochemistry (M.L., Bordenave, ed.), p. 373-394

Ünüçok C (1985). Geological Survey and Reserve Report of Tuzköy Rock Salt Mine (Nevşehir-Gülşehir), Mineral Research and Exploration (MTA), Report No. 7897

Volkman J K \& Maxwell J R (1986). Acyclic isoprenoids as biological markers. Biological Markers in the Sedimentary Record (R.B. Johns, eds.), Elsevier, New York; 1-42

Waples D W (1985). Geochemistry in Petroleum Exploration. International Human Resources Development Corp., US.

Wedding $\mathrm{H}$ (1967). A Coal Prospection in Dadağ (Nevșehir-Gülșehir). Mineral Research and Exploration (MTA), Report No. 3927

Zemo D A \& Foote G R (2003). The technical case eliminating the use of the TPH analysis in assessing and regulating dissolved petroleum hydrocarbons in groundwater. Ground Water Monitoring \& Remediation, 23(3), 95-104

Zheng Y Zhou W Meyers PA \& Xie S. (2007) Lipid biomarkers in the Zoigê- Hongyuan peat deposit: Indicators of Holocene climate changes in West China. Organic Geochemistry, 38: 1927-1940. 